\title{
Maternal behaviour in Mus musculus sp.: An ethological review
}

\section{Elin M. Weber ${ }^{a, b},{ }^{*}$, I. Anna S. Olsson a}

a Laboratory Animal Science, IBMC-Institute for Molecular and Cell Biology, Rua Campo Alegre 823, 4150-180 Porto, Portugal

b Department of Animal Environment and Health, Swedish University of Agricultural Sciences, PO Box 234, 53223 Skara, Sweden

Originally published in Applied Animal Behaviour Science 114 (2008) 1-22 doi:10.1016/j.applanim.2008.06.006

* Corresponding author at: Department of Animal Environment and Health, Swedish University of Agricultural Sciences, PO Box 234, SE-532 23 Skara, Sweden. Tel.: +4651167122; fax: +4651167 204 . E-mail addresses: elin.weber@hmh.slu.se (E.M. Weber), olsson@ibmc.up.pt (I.A.S. Olsson). 


\begin{abstract}
In this paper, we review the scientific literature on maternal behaviour in commensal house mice and laboratory mice. Similar to other altricial species, female mice prepare a nest before parturition. Once the pups are born, nursing is the main part of maternal behaviour, and pups are weaned through a gradual non-aggressive process after about 3 weeks. Mice are social and both males and females show parental behaviour. Female mice giving birth at about the same time form communal nests, where pups are also communally nursed, a phenomenon that may confer benefit in inclusive fitness. However, social living may also be risky with conspecifics being the main predators of pups. A distinct aggressive behaviour pattern shown by pregnant and lactating female is thought to protect nest and pups against such attacks. Maternal aggression is influenced by the presence of pups and by litter size and composition. Communication through external stimuli from the pups contributes to maintaining maternal behaviour, thereby influencing pup growth. Handling of infants and pre-and peri-natal stress affects maternal behaviour. When resources are limited, females may reduce litter size through infanticide; however, the phenomenon of maternal cannibalism under normal laboratory conditions is poorly understood. Many studies included in this review use only standard tests to measure maternal behaviour, and more ethological research would be valuable to understand problems with reproduction in laboratory strains as well as to understand the influence of different housing conditions.
\end{abstract}

Keywords: Mice; Parental; Nursing; Nestbuilding; Nesting; Infanticide

\title{
1. INTRODUCTION
}

House mice ${ }^{1} 1$ are characterized by their fast reproduction and adaptive ability, contributing to their great success in occupying many different habitats all over the world (Bronson, 1979; Silver, 1995). In some geographic areas house mice switch between commensal (dependant on human shelter and activity for survival) and feral (no longer dependant on humans) states, according to the season. Mice cohabit with humans in many ways. In some areas wild house mice are considered agricultural pests, and commensal mice destroy wood, clothing and may spread diseases (Walker and Nowak, 1999; Morton, 2002). On the other hand, selectively bred mice are valued as experimental organisms in biomedical research.

\footnotetext{
${ }^{1}$ In this review, the term house mice/laboratory mice refers to M. musculus. All laboratory and commensal mice belong to this species, which has four subspecies: Mus musculus domesticus, M. m. musculus, M. m. castaneus, and M. m. bactrianus. Although the four have non-overlapping ranges in the wild and are morphologically and molecularly distinct, they can reproduce and produce fertile offspring in the laboratory. Among the hundreds of inbred strains represented in laboratories all over the world, none of the original strains originate in only one house mouse subspecies, but data suggest that M. m. domesticus is predominant (Silver, 1995).
} our publications, please visit http://repositorio-aberto.up.pt/ 
Maternal behaviour influences the probability of survival (Cohen-Salmon, 1988). The term "maternal behaviour" covers a wide range of behaviours. Causey and Waters (1936) were the first to demonstrate the many phases included in parental care in mammals (Cohen-Salmon, 1988): nest building by one or both parents, incubation, feeding behaviours, protection of the young and training of young. Capabilities to feed or adopt young within and across species, abandonment, and devouring of young were also included, but considered aberrations. Free-living mice are nocturnal (Sayler and Salmon, 1971; Walker and Nowak, 1999) and often live in burrows (Berry, 1970), making observations in the natural habitat difficult. Therefore most investigations concerning maternal behaviour are laboratory studies.

Even in the protected laboratory environment, maternal behaviour is crucial for the survival of the altricial mouse infants. Loss of newborn litters is not uncommon in laboratory strains and some genetically modified strains show poor maternal behaviour (Nelson and Young, 1998; Alston-Mills et al., 1999). Nevertheless, almost nothing is known about the background of unsuccessful maternal care. A better understanding of maternal behaviour and the influencing factors will be useful to address problems in laboratory animal facilities. This paper aims to review maternal behaviour as an adaptive trait affecting fitness through pup survival. We will highlight nestbuilding, communal nesting and nursing, maternal aggression, vocal communication, stress, genetics, infanticide and cannibalism, and methods used to measure maternal behaviour. Conflicting results will be discussed in relation to differences between strains, handling methods, housing conditions and observation techniques.

\section{Social organization and reproductive behaviour}

Social organization may vary between different mouse populations. Bronson (1979) described two common types of populations: commensal and feral. Commensal populations live in territories with stable and plentiful food supply and a population density of up to 10 mice per m2. Feral populations are less dense (up to 1 mouse/10o m2), spatially instable and found in environments with seasonally unstable food supply. Commensal populations live in territories with a single dominant male, a few subordinate males and several breeding females with offspring, while feral populations typically have unstable social organizations with a high turnover rate. Commensal house mice show no difference in breeding intensity throughout the year, while feral mice have been described as seasonal (Berry, 1970). However, Bronson (1979) argued that feral mice are facultatively seasonal and breed all year in temperate zones, suggesting that the capacity of continuous and rapid breeding is only limited by environmental factors.

Under favourable conditions, female house mice sexually mature around the age of 6-8 weeks. They are short-cycling, with an oestrus cycle that varies from 4 to 6 days (Bronson et al., 1966; Berry, 1970), have a spontaneous ovulation and produce many large litters (Bronson, 1979). The lengths of individual cycles are variable and influenced by the season, diet, and environment (e.g. Baumans, 2004). The size of the mother also influences litter size, with larger females producing more ova (Berry, 1970). Reproductive performance also varies widely among different inbred strains (Silver, 1995).

(


Fertilization is possible about 10-12 h after ovulation and gestation lasts for 19-21 days (e.g. Labov et al., 1985; Baumans, 2004). Parturition usually takes place during the night, and is followed by post partum oestrus with ovulation 12-18 h after giving birth (Berry, 1970).

\title{
3. Pup development
}

At birth the young weigh approximately $1 \mathrm{~g}$, are hairless (except for whiskers), blind, deaf, have undeveloped motor skills and are fully dependent on their mother for nutrition and thermoregulatory control (see e.g. Ewer, 1968; König and Markl, 1987). Hearing ability seems to appear by the fourth or fifth day, and by day 6 the pups are completely covered with a thin coat of first hair. They open their eyes between day 12 and 14 postpartum (Williams and Scott, 1953; Fuchs, 1981), and after this the first extensive activity outside the nest occurs. However, except when exploring, the eyes are often kept tightly closed until days 15 or 16. At this age, the pups' hair coat is also fully developed. Until day 16 litters are often seen nursing, but at the age of 17 days the pups start to eat solid food and the first signs of weaning are noted (Williams and Scott, Markl, 1987). Drinking from the water tube was first observed on day 20 (Williams and Scott, 1953). At weaning the young weigh around 10 $\mathrm{g}$, depending on the amount of milk available, which in turn depends on litter size.

\section{General aspects of maternal behaviour}

Maternal behaviour in the mouse starts during early gestation with the preparation of the brood nest (see Section 5) (Ewer, 1968; Berry, 1970; Lisk, 1971). Maternal behaviour of wild caught Mus domesticus (F1 generation) was quantitatively analysed by König and Markl (1987), observing females with litter during the entire lactation period of 28 days. Nursing, licking, grooming young and nest building were considered as being maternal behaviours. During the first 3 weeks, nursing occupied $92 \%$ of the maternal behaviour. Initially the mother spends almost all her time curled around the pups in the nest (Williams and Scott, 1953; Ewer, 1968), and the female was not seen resting alone without body contact to any pups until day 9 (König and Markl, 1987). Weaning seemed to take place gradually, with no observations of aggression towards young. Initially, the mother always initiated nursing, with suckling initiated by pups first seen at day 13 , and becoming more frequent during days 17-22. The weaning age of 23 days was judged from a drop in nursing activity to less than $1 \%$. After day 23 , nursing was replaced by resting with body contact without offspring trying to suckle. Williams and Scott (1953) observed the normal behavioural development of undisturbed mice under usual laboratory conditions, and found that weaning was completed by day 25 , when the last nursing event was seen. ${ }^{2}$

\footnotetext{
${ }^{2}$ In laboratory animal facilities, weaning is typically imposed at 21 days, corresponding to the time when the next litter will be born if the female was mated postpartum.
}

\author{
.
}




\section{Nest building}

All mice build nests in which they sleep, and so two types of mouse nests are often referred to: sleeping nests or thermoregulatory nests (relatively small, often saucer shaped open nests built by non-pregnant mice) and brood nests or maternal nests (built by the female from approximately 4 days after mating, 2-3 times the size of a sleeping nest, with one or two entrances and completely enclosed) (e.g. in Gandelman, 1973a; Lynch, 1981; Schneider and Lynch, 1984; Schneider et al., 1982). Since mice are born ectothermic and have poor thermoregulatory abilities up to 2-3 weeks of age, the construction of a brood nest is important for successful rearing of young (Lynch and Possidente, 1978). In the wild, mice generally build nests of hair, grasses and other soft plants (Alcock, 1993; Jensen, 1993), and in the laboratory cellulose-based nesting material is often provided (although in many of the studies reviewed no nesting material was provided). When comparing different bedding materials through habitat preferences, including an option with no bedding material present, Iturrian and Fink (1968) found that none of the mice gave birth in cages without bedding. Further, providing extensive nesting and burrowing opportunities has been found to be crucial for successful breeding of wild mice in the laboratory (Wallace, 1981).

To test the hypothesis that nest building was an important component of fitness, Bult and Lynch (1997) compared mice that had undergone divergent selection to create two lines, one showing high levels of and one showing low levels of thermoregulatory nesting. The mice were randomly divided to produce mating pairs of each line, and then maintained in two different temperatures ( 221 and 4 $18 \mathrm{C}$ ). Nest building was positively correlated with the number of young born and weaned, and total of young per family surviving up to 40 days of age, indicating the importance of nest building for fitness. Similarly, in mice bidirectionally selected for thermoregulatory nest building, survival of young was significantly lower at $58 \mathrm{C}$ in small nests (Lynch and Possidente, 1978). This study also showed a major influence of ambient temperature on nest size and it was suggested that mice are capable of adjusting the maternal nests according to changes that can affect litter survival.

Strain differences in nest building behaviour were found in several studies (e.g. Broida and Svare, 1982b, 1983; Schneider et al., 1982; Brown et al., 1999; Bond et al., 2002), however, the results are ambigous, as further discussed in Section 10. Great individual variation in nest building behaviour has also been reported (Lynch and Possidente, 1978).

Mice have been reported to differ from other altricial species such as rats and rabbits in that the maternal nest is prepared so early in gestation (Lisk, 1971; Lisk et al., 1969). Lisk et al. (1969) reported that nest size continues to increase throughout gestation until 1 day prepartum, and then gradually decreases after parturition, while other authors report a peak in the amount of nest material used around days 12-14 of pregnancy (Broida and Svare, 1982b).

Lisk et al. (1969) investigated the role of the hormones progesterone and oestradiol in eliciting maternal nest building; mean nest weight decreased after oestradiol treatment and increased after implantation of progesterone or a combination of oestradiol and progesterone (see also Schneider et al., 1982); these hormones seem to act in synergy to facilitate maternal nest building (Lisk, 1971). Pup vocalization also influences nestbuilding; Noirot (1974) found that exposing virgin females to pup ultrasounds induced nestbuilding behaviour. 
Several experiments have demonstrated the importance of nestbuilding for the survival of offspring (e.g. Lynch and Possidente, 1978; Bult and Lynch, 1997). It has been argued that behaviours essential for survival in the wild will remain highly motivated also in domestic animals in captive environments (Dawkins, 1990, 1998). In a series of experiments, Roper (see Olsson and Dahlborn, 2002) demonstrated that non-reproductive mice show high nestbuilding motivation. To our knowledge, there are no studies of motivation for nestbuilding in pregnant mice; however, just as nonreproductive mice (reviewed in Olsson and Dahlborn, 2002) also pregnant mice show a preference for an environment with nesting material (Iturrian and Fink, 1968). Given the relation between thermoregulatory and maternal nestbuilding (e.g. Lynch, 1981), a common motivational background for the two behaviours seems likely. While the nest clearly affects pup survival and welfare, the possibility to satisfy nestbuilding motivation will also affect female welfare. Caution is necessary when extrapolating from experimental conditions to fitness in nature, in particular given the highly artificial measure of nestbuilding used in several of the experiments, where the nest is removed every day and the total weight of material to build a new nest is measured (e.g. Lisk et al., 1969; Lee, 1973; Lynch and Possidente, 1978; Broida and Svare, 1982b; Schneider and Lynch, 1984); in nature the female is likely to maintain the same nest throughout pregnancy and lactation.

\section{Communal nesting and nursing}

Existing guidelines and assessment frameworks 45 typically refer to aspects such as frequency, Communal care is defined by Hayes (2000) as the sharing of parental responsibility by multiple individuals', and communal nesting is the form of communal care where multiple females raise young in the same nest. Communal nesting is seen among birds (McRae, 1996; Hayes, 2000) and in many mammals (Packer et al., 1992). Communal nesting may be a result of individuals congregating around clumped resources, or may also be an adaptive strategy, improving thermoregulation and nest defence, and perhaps skills that help in future reproduction (see Hayes (2000) for a rodent-specific review). A communal nest is usually formed by pairs or groups of females residing within one male's territory and giving birth in a shared nest (Manning et al., 1995).

Besides forming communal nests, house mice also seem to nurse their pups communally (Sayler and Salmon, 1971; Wilkinson and Baker, 1988; Packer et al., 1992; Manning et al., 1995). Communal nursing has been reported in the laboratory (e.g. Sayler and Salmon, 1971; König, 1994), in seminatural environments (Manning et al., 1995), and in the wild (Wilkinson and Baker, 1988). Nonoffspring nursing is most common in taxa with large litters such as pigs and rodents (Packer et al., 1992). Communal nursing has energetic and potential fitness consequences, especially in an environment with limited food supply for the dam, such that she may not be able to provide enough milk for her own offspring survival (Wilkinson and Baker, 1988). Pups may benefit from milk from multiple females; females on the other hand may pay a fitness price through nursing more pups than their own genetic offspring (see Hayes, 2000). There is also a fitness conflict in that females should prefer multiple mothers for their own pups, but not for the pups of competitors (Wilkinson and Baker, 1988). 
Different aspects of communal nursing in BALB/C ${ }^{3}$ mice were analyzed by Sayler and Salmon (1969, 1971). Females would consistently combine their young in one nest after being separated from similar groups with a barrier. Communal nursing was only inhibited when age between litters differed more than 5 days, with an increasing aggressive tendency displayed by the mother of the younger pups. Further, it was reported that each communal nesting female spend less time nursing than a solitary female. However, until day 14 postpartum, young in communal groups spent longer time nursing and young mice grew faster with multiple mothers, even though the ratio of mothers to young was held constant and thus communal nesting did not increase milk availability.

Manning et al. (1995) tested the hypothesis that survival is greater in communal nests. Pup loss during the first 3 days was $86 \%$ in single-mother and $56 \%$ in communal nests. The probability of surviving to weaning was $69 \%$ in communal nests compared to $33 \%$ in single nests. There was also a higher probability of losing all pups in single-mother nests (56\%) compared to communal nests ( $9 \%)$. This indicated that an important advantage from communal nesting is increased pup survival. Only a few occasions of infanticide were observed, but pups were found bitten about the head and thorax, and the enclosure was free from predators. The authors thus suggested that the main benefit from communal nesting is enhanced nest defence decreasing conspecific infanticide. Both male and female mice are reported to kill conspecific young under certain circumstances (see Section 12), and therefore nest defence can be of high importance for litter survival (see Section 7).

The relatedness of communally nesting females and their offspring is another important aspect. Under natural conditions, nestmates who grow up in communal nests typically have the same father and females sharing a communal nest are often related. Therefore there is a high probability of nursing closely related offspring when nesting with a familiar female (König, 1994). In this case females would gain inclusive fitness benefits from nursing the pups of their nest mates (see e.g. Wilkinson and Baker, 1988; Hayes, 2000; Bourke, 2001; Emlen, 2001).

To investigate the role of relatedness and familiarity on the formation of communal nests, König (1994) cross-fostered new born female mice. Females were kept in pairs, according to familiarity and relatedness. Communal nesting with a familiar female (irrespective of relatedness) improved female reproduction and increased offspring survival. Furthermore, groups with females that where both familiar and related produced both largest litters and heaviest offspring, the later in agreement with the findings by König (1993). In general, offspring born into large litters are lighter both at birth and weaning compared to pups in small litters (Fuchs, 1981; Mendl, 1988).

Also the male may play an important role in rearing offspring (see review in Elwood, 1983). Apart from nursing, males show the same parental care as females (König and Markl, 1987; Ostermeyer, 1981) and Wright and Brown (2000) even reported that pups housed with both parents received twice as much parental care.

Wilkinson and Baker (1988) listed three conditions under which communal nesting benefits participants: (1) if improving heat retention, with consequent improved pup survival and growth; (2) if increasing pup growth due to increased milk production by two females; (3) if fewer pups were lost to predators because of higher nest defence. Even though Sayler and Salmon (1971) found that

${ }^{3}$ Throughout this review, names of strains will be given according to the Rules and Guidelines for Nomenclature of Mouse and Rat Strains (http://www.informatics.jax.org/mgihome/nomen/strains.shtml) 
communal nesting improved pup growth and Manning et al. (1995) found that it enhanced litter survival, the phenomenon of communal nursing is complex and cannot be easily explained.

Sayler and Salmon (1971) suggested that improved heat retention was not an important aspect of communal nesting since introduction of a virgin female did not result in increased pup growth. However, total time the virgin spent in the nest was not reported, drawing into question this conclusion. We suggest that the enhanced thermoregulation hypothesis could be tested by comparing communal nesting in different habitats and at different temperatures.

An alternative explanation of communal nursing could simply be that it is an unavoidable byproduct of communal nesting. It might be difficult for polytocous species to nurse own pups while at the same time blocking milk access to non-offspring (Packer et al., 1992), or the cost for nursing non-offspring may be lower than the cost of discriminating between own and non-offspring (Hayes, 2000). Given the social organization of mice, where most communal nursing is likely to confer a gain in inclusive fitness for females that nurse closely related offspring, there may have been little selection pressure against the potential cost of nursing non-related pups. Even so, cross-fostering studies have demonstrated an effect of the genetic relatedness between females and offspring, in that mothers nursing fostered offspring of their own strain invest more resources (Hager and Johnstone, 2003) and pups nursed by their own mother show larger relative weight gain during late lactation (Hager and Johnstone, 2005) than unrelated mother-pup combinations. 


\section{Maternal aggression}

The term maternal aggression refers to the aggressive behaviour of a lactating female defending her offspring. In the wild, nests are usually hidden inside walls or underground and predation by nonconspecifics is probably rare (Wilkinson and Baker, 1988). Instead, one of the major predators of neonate rodents are conspecifics (Ostermeyer, 1983), and their presence around the nest can influence litter survival (vom Saal et al., 1995; Mandillo and D'Amato, 1997). Many authors have demonstrated that both pregnant and lactating females display maternal aggression (e.g. Ostermeyer, 1981; Broida and Svare, 1982a; Elwood et al., 1990; Maestripieri and Alleva, 1990; vom Saal et al., 1995). Maternal aggression possesses a number of unique features in terms of response topography, initiation mechanism, hormonal mediation, and target selectivity and can thus be categorized as a distinct type of aggressive behaviour (see Ostermeyer, 1983 for a review). Attacks from maternally aggressive females typically have a rapid onset and are potentially damaging in nature. When exposed to these attacks, males often flee or react with defensive postures, but in some cases they then retaliate and kill the offspring (vom Saal et al., 1995). The sensory, hormonal, neuroanatomical and neurochemical mechanisms underlying maternal aggression has been thoroughly reviewed by Lonstein and Gammie (2002) and are not addressed here.

During lactation females do not ovulate and are thus not available for successful mating (Alcock, 1993). According to Hrdy's sexual selection hypothesis, males benefit from killing non-related pups as this allows the female to return to oestrus, providing the male an earlier opportunity for mating and thus increased reproductive success (Labov et al., 1985; Blaffer Hrdy, 1979). Females fight in order to protect the investment they already made in the young (Ostermeyer, 1981), and research suggests that maternal aggression functions to protect the litter from infanticidal intruders (Elwood et al., 1990; Maestripieri and Alleva, 1990; Wolff and Peterson, 1998).

Maestripieri and Alleva (1990) examined the intensity of female postpartum aggression in relation to litter size by randomly assigning females to different groups according to number of pups. Maternal aggression was only displayed in the groups where pups were present, suggesting a strict relation to pup defence. The intensity of aggression also increased with increased litter size.

To investigate if litter defence depended on litter composition and food availability, Maestripieri (1991) randomly divided female mice into two groups: food restricted and control group. Litters were also manipulated short after parturition to obtain three different compositions: 10 males (MM), 10 females (FF) and 5 males/ 5 females (MF). In the control group, females in MM groups had a higher score of maternal aggression. Furthermore, food restricted MM and MF females showed lower total attacking time than their control group. These results suggest that litter composition do affect maternal aggressive behaviour.

Mandillo and D'Amato (1997) presented female mice to odours of different males with different infanticidal potential. The female took longer time to reach the pups when exposed to the odour of a potentially infanticidal male and significantly longer time to reach the 8-day-old pups, compared to 4 and 12-day-old pups. This age difference may have been due to females placing different value on pups of different ages. 
To minimize energy losses, females would benefit from discriminating between animals that pose a threat to her investment and those who do not, and only attack if the pups are in danger (Elwood et al., 1990). A test of this hypothesis showed that female mice did discriminate between infanticidal and non-infanticidal males. The rate of maternal aggression also depended on whether the litter was present or absent. With pups present, the female attacked the infanticidal male more than she attacked the non-infanticidal male, but when the pups were absent the female made no distinction in her behaviour towards the males (Elwood et al., 1990). Other work has shown that familiar males are not attacked (Lonstein and Gammie, 2002). vom Saal et al. (1995) showed that lactating females displayed very high rates of aggression towards both male and female intruders, and previously infanticidal females (i.e. females showing infanticidal behaviour during a screening test) were more aggressive towards intruders than non-infanticidal females.

The tendency to display maternal aggression differs between strains (Ostermeyer, 1981 ; vom Saal et al., 1995), individuals (Broida and Svare, 1982a), and locations. For example, Paul et al. (1980) found that maternal aggression was stronger in the home cage than in a test arena. If nest-sites are a limiting resource, maternal aggression may also serve to protect the nest-site (Ostermeyer, 1983). In addition to infanticide, males may also increase their mating success through a pregnancy blocking phenomenon, also called the "Bruce effect" (Ostermeyer, 1983; Manning and Dawkins, 1998; Latham and Mason, 2004). This phenomenon causes a pregnant female to abort the litter and reabsorb the embryos (Manning and Dawkins, 1998) when exposed to an unfamiliar male. The female returns to oestrus within 4 days after first exposure to the male (Bruce, 1961). Females are most vulnerable to exposure to a strange male within $48 \mathrm{~h}$ postmating, but they are susceptible to pregnancy block during the first 4 days after copulation. The duration of exposure required to induce a block varies from 12 h to 2 days (Bruce, 1961).

The findings in the above-mentioned studies propose several contradictory suggestions for the actual function of maternal aggression. While some authors report maternal aggression only when pups are present (Elwood et al., 1990; Maestripieri and Alleva, 1990; Ebensperger, 1998), others argue that the presence of a litter is not necessary (Paul et al., 1980). The latter could be expected if maternal aggression serves to defend a nest-site rather than the litter, e.g. in environments with limited resources (Ostermeyer, 1983). However, the effect of litter size on maternal aggression (Maestripieri and Alleva, 1990) suggests that pup defence is at least part of the explanation for the behaviour. Most commonly, maternal aggression has been reported to function mainly as protection against infanticidal conspecifics. But maternal aggression does not always succeed in keeping the litter from harm: male mice have been reported to kill pups despite the female's aggressive behaviour (Ostermeyer, 1983; Elwood et al., 1990). This may differ in the wild, where it is more likely that the nest has a narrow entrance (a relatively small area to defend), and the intruders are able to retreat (Ebensperger, 1998). Nevertheless, Ebensperger (1998) found that in the laboratory the presence of a protected nest and chance to retreat did not increase the female's success in defending the litter against an infanticidal male.

\section{Pup behaviour and vocal communication}

During the first 5 days postpartum, spontaneous licking, changing suckling position, and nestbuilding decrease in female mice, and external stimuli from the pups are crucial for maintaining maternal care (Cohen-Salmon et al., 1985; Ehret and Bernecker, 1986). Although born with non-functional auditory systems (Porter, 1983), young rodents of several species use vocalizations (Elwood and McCauley, 
1983). During the first 2-3 weeks postpartum, pups emit a variety of ultrasonic vocalizations (USVs) when isolated from the mother (Branchi et al., 1998), and wriggling calls increase between birth and day 5 postpartum (Ehret and Bernecker, 1986), functioning to maintain maternal behaviour at a high level. Elwood and McCauley (1983) distinguished between three categories of infant calls: ultrasounds, audible squeals and clicks. Furthermore, Ehret and Bernecker (1986) categorized ultrasonic sounds according to the response triggered in the mother: pure ultrasounds inducing pup approach and retrieving, broadband pain calls inhibiting injury, and low-frequency wriggling calls eliciting maternal behaviour and particularly licking. Environmental conditions also influence the emission of calls: the frequency at which different types of calls were emitted differed between situations of maternal isolation, isolation and low temperature, tactile stimulation and male odour exposure (Branchi et al., 1998).

Rodent vocalizations and their functions have been subject to several reviews (e.g. Porter, 1983; Elwood and McCauley, 1983; Brudzynski, 2005; Hahn and Lavooy, 2005; Ehret, 2005). Producing calls could be energetically costly and increase the risk of being detected by predators (Ehret and Bernecker, 1986), so counterbalancing benefits should be expected. Ehret and Bernecker (1986) examined the function of wriggling calls in outbred mice by manipulating female hearing ability and pup activity. Four experimental groups with different communicative abilities were created: three with surgically treated females (bilaterally deafened, unilaterally deafened, sham-operated normal hearing) with active pups, and one with intact normal hearing females with pharmacologically tranquilized pups. Pups were found to emit wriggling calls regularly during suckling, and always in association with pup movements. Females with paralysed pups responded to playback wriggling calls, but active, moving pups did not act as an effective stimulus for releasing maternal behaviour in deafened mothers. Offspring to bilaterally deafened mothers showed impaired weight development compared to the other groups. Altogether, these results show that wriggling calls are important for eliciting maternal behaviour and for normal pup development.

However, inbred strains of mice have been reported to have poor ultrasonic hearing and some strains are deaf (Cohen-Salmon et al., 1985). Cohen-Salmon et al. (1985) observed eight inbred strains in various experiments, and found differences both in amount of USV emitted and in the females' abilities to perceive the calls. Using cross-fostering, Hennessy et al. (1980) found that pup strain affected post-handling behaviour in that $\mathrm{A} / \mathrm{J}$ pups were more rapidly retrieved, possibly because they emitted more ultrasound signals, and $\mathrm{C}_{57} \mathrm{BL} / 6 \mathrm{~J}$ pups more licked. Elwood (1991) and Noirot (1972) reported that pup cannibalism was associated with maternal hearing disabilities; however, Busnel and Lehmann (1977) did not find any difference in cannibalism or pup retrieval between deaf mutants and hearing wild-type mice. D'Amato et al. (2005) hypothesized a genetic relation between maternal responsiveness and pup calling, so that pups of more responsive mothers would emit less calls. This was confirmed in a study with $\mathrm{BALB} / \mathrm{C}$ and $\mathrm{C}_{57} \mathrm{BL} / 6$ mice, in which $\mathrm{C}_{57} \mathrm{BL} / 6$ females showed a shorter latency to leave the starting compartment of the test cage to retrieve pups in an unfamiliar environment, and isolated $\mathrm{C}_{57} \mathrm{BL} / 6$ pups emitted less USV.

Injecting pups with sickness-inducing endotoxins models the effect of a naturally occurring immune challenge and alters maternal behaviour. Immediately after injection, females were less responsive to endotoxin-injected than to saline-injected pups. The effect included a longer latency for some dams to retrieve injected pups, which might have been influenced by lower levels of ultrasound vocalization. At the time when the peak in sickness behaviour usually occur ( $3 \mathrm{~h}$ post-injection), the 
maternal care directed towards endotoxin-injected pups was enhanced compared to saline-injected (Hood et al., 2003).

A complex sequence of interdependent mother-pup interaction is described for rats, with two distinct phases: an initial phase of maternal handling and licking followed by the suckling/ nursing phase (reviewed in Hood et al., 2003). Less is known about the mother-pup organization of mouse maternal behaviour; however, the reported results clearly suggest a similar co-organization of behaviour. Calls from the pups are crucial for maintaining maternal behaviour (Ehret and Bernecker, 1986) and despite potential disadvantages of increased risk of predation and energetic cost of producing calls mouse pups emit several different vocalizations to solicit the mother's attention (Elwood and McCauley, 1983; Ehret and Bernecker, 1986). The risk of inappropriate maternal responses and increased pup mortality due to hearing deficiencies need to be taken into account when using inbred or genetically modified strains of mice (Cohen-Salmon et al., 1985). Hood et al. (2003) suggested that the altered pattern observed in females caring for endotoxin-injected pups may reflect a delay in moving from a licking and handling phase to the nursing phase, as a result of sick pups being less active.

\section{Stress}

In homeostatic terms, stress can be defined as "a departure from the organism's usual state of equilibrium", and a stressor is a condition or event causing the departure (Mason, 2000, p. 277). In the wild as well as in the laboratory, mice are subject to different stressful situations, including disease, pain, aggression, restraint, isolation, social instability, loss of predictability and loss of control.

Early life experiences affect many behaviours (Lay, 2000; Mason, 2000), and there has been extensive research into the effect of different stressors on maternal behaviour and offspring development (e.g. Priestnall, 1973; Lee and Williams, 1974; Sherrod et al., 1974; Pardon et al., 2000; Meek et al., 2001; Macri and Würbel, 2007). When administering stress to pregnant rodents, noxious treatments such as thermostress, injections or immobilization are generally used, and chronic stress is obtained through repeated exposure (Pardon et al., 2000). Another approach is the chronic mild stress (CMS) protocol, where stressors such as overnight illumination, periods of food and/or water deprivation, cage tilt and change of cage mate are sequentially administered over a period of weeks or months (Willner, 1997).

Prepartum stressors influence maternal behaviour, as demonstrated by Pardon et al. (2000). Reducing the intensity of the CMS protocol, a chronic ultramild stress (CUMS) protocol was created and administered from the end of the mating period to postpartum: cage tilt, reduced cage size, paired housing, overnight period with either difficult access to food, permanent light or soiled cage. CUMS did not affect nestbuilding behaviour but affected the mothers' ability to protect the pups against a male intruder. CUMS females did not respond aggressively to the intruder. Instead they retrieved pups and returned them into the nest, despite that this nearly always confronted them with the aggressive male. Meek et al. (2001) administered chronic, psychological stressors to pregnant and lactating females, and created different combinations of prepartum and prenatal stress by crossfostering pups over treatments: non-stressed dam:nonstressed cross-fostered pups (NS:NS), stressed dam:non-stressed cross-fostered pups (S:NS), non-stressed dam:stressed cross-fostered pups (NS:S), stressed dam:stressed cross-fostered pups (S:S). The stressors used were: hot, bright 
light (days o-8) and loud music (days 9-16); and delivered three times daily for 45 min each time. No water was provided during the stress period. Dams raising pups with different stress experience than themselves (S:NS and NS:S) showed decreased rates of grooming, nursing and time in nest. Nonstressed dams raising stressed pups (NS:S) also demonstrated fewer attacks in a maternal aggression test compared to S:NS and S:S groups, and retrieved pups significantly more slowly than any other group. Stressed dams raising stressed cross-fostered pups $(\mathrm{S}: \mathrm{S})$ showed high levels of pup retrieval and maternal aggression.

The effect of early handling (pups removed from the home cage for several minutes) on offspring in terms of decreased behavioural and endocrine response to stress persisting into adulthood, was first demonstrated by Levine in the early 1960 s and has been widely studied in rats (reviewed in Pryce and Feldon, 2003). Priestnall (1973) demonstrated that the early handling protocol extensively applied in rats (e.g. Macrı' et al., 2004) produces comparable effects in mice. Females were divided into three groups 7 days postpartum: litter handled, mother handled, and neither litter nor mother handled. Mothers of handled litters groomed their offspring more, indicating that handling changes the behaviour of the mother. Later research reported similar effect of handling pups (Sherrod et al., 1974i Hennessy et al., 1980; D'Amato et al., 1998) but not of handling the female (Moles et al., 2004).

Chronic (ultra)mild stress and early handling are protocols widely applied on rodents in neurobiological and pharmacological research. The chronic mild stress protocol is usually applied to adult animals to produce a model of depression, primarily characterized by decreased responsiveness to positive events (Willner, 1997). The early handling protocol on the other hand is applied to pups, and affects their stress response later in life (see above).

Removing the litter from the cage disturbs the cage environment and can be expected to change the female's behaviour (Lee and Williams, 1974, p. 679). Further, when exposing pups to different stressors, handling is almost always a part of the procedure. It is therefore difficult to distinguish what alters the behaviour in the pups, the stressor or the handling procedure. Also the effect of early handling seems to be mediated to a large extent through alterations in mother- infant interactions, including changes in levels and temporal distribution of maternal care (e.g. Mason, 2000). Pryce and Feldon (2003) also point to the potential role of alterations in infant behaviour (see also Macri' and Würbel, 2006). This latter suggestion is consistent with the results reported by Meek et al. (2001) that both mother and offspring stress affect the behaviour of the mother. However, Meek et al. (2001) measured only female behaviour and in the absence of information on how pup behaviour changes it is difficult to draw conclusions from this study. An important consideration when interpreting the results of early handling studies is the type of control group; handling animals as little as weekly during normal husbandry procedures has been demonstrated to affect behaviour. Therefore, complete absence of handling does not resemble a normal postnatal environment but rather a situation where pups are under-stimulated, yielding adults exhibiting abnormal behaviour, suggesting that absence of handling in itself should be considered an experimental treatment rather than a control group (Pryce and Feldon, 2003).

\section{Genetic influence}

Transgenic studies with null mutations have demonstrated several individual genes involved in the regulation of maternal behaviour (see Bridges, 1998 for an overview). In a study of F2 and subsequent 
crosses of two inbred mouse strains, Peripato et al. (2002) found two quantitative trait loci (OTL) affecting maternal performance measured as successfully rearing offspring to 1 week of age. The authors reported ${ }^{4}$ that offspring survival is associated with whether or not females engage in prepartum nestbuilding, suckling and pup retrieval. An inbreeding effect on offspring survival was associated with milk provision and aggressive behaviour and pup retrieval. In research preceding the introduction of molecular genetics, focus was on strain differences and to some extent selection effects on both pre-and post-partum maternal behaviour. Measuring the amount of nest material used in progesterone-implanted non-pregnant females and in females on days $5-2$ preparturition, Schneider et al. (1982) found that BALB/CByJ females built the largest nests and DBA/1J females the smallest nests, with $\mathrm{C}_{57} \mathrm{BL} / 10 \mathrm{Sn}$ and $\mathrm{CR}_{3} \mathrm{H} / \mathrm{Hej}$ showing intermediate nest sizes. The strain order was the same for progesterone induced nesting and maternal nesting. Broida and Svare (1982b) on the other hand found that pregnant DBA/2J females used more cotton and exhibited higher median values for nest quality than $\mathrm{C}_{57} \mathrm{BL} / 6 \mathrm{~J}$ females, a strain difference that seem to be principally genetically controlled as it resisted cross-fostering and increasing experience. Mice from strains selected for high and low levels of thermoregulatory nesting (in males and non-pregnant females) showed corresponding differences in maternal nesting, indicating a common genetic basis for the two behaviours (Lynch, 1981).

Brown et al. (1999) found a difference between $\mathrm{C}_{57} \mathrm{BL} / 6 \mathrm{~J}$ and $\mathrm{DBA} / 2 \mathrm{~J}$ females, in particular in interacting with their first litter. When undisturbed, primiparous $D B A / 2 J$ mice spent more time on maternal behaviour than $\mathrm{C}_{57} \mathrm{BL} / 6 \mathrm{~J}$ mice, with more time crouching over and nursing pups, while $\mathrm{C}_{57} \mathrm{BL} / 6 \mathrm{~J}$ mice spent more time retrieving pups. These strain differences were not present with the second litter. After the pups had been removed and returned, $\mathrm{C}_{57} \mathrm{BL} / 6 \mathrm{~J}$ mice spent more time nestbuilding and retrieving pups. These differences were evident with both the first and the second litter. In both parities, $\mathrm{C}_{57} \mathrm{BL} / 6 \mathrm{~J}$ litters were larger and had larger mortality. The increased time spent nestbuilding in $\mathrm{C}_{57} \mathrm{BL} / 6 \mathrm{~J}$ females was reflected in nests with better enclosure (Bond et al., 2002). Using a cross-fostering approach, Hennessy et al. (1980) found a strain difference in maternal behaviour only after pup handling, when $\mathrm{C}_{57} \mathrm{BL} / 6 \mathrm{~J}$ mice were faster to retrieve pups and spent more time nestbuilding and less time nursing, pup-carrying and self-grooming than $D B A / 2 J$ mice. Undisturbed females spent more time nursing and in the nest if they had a litter of their own strain. Anisman et al. (1998) found BALB/CByJ and $\mathrm{C}_{57} \mathrm{BL} / 6 \mathrm{ByJ}$ mice to differ in maternal behaviour in that $B A L B / C B y J$ mothers spent less time in arched back nursing, less time attending to the pups and less time in the nest.

That maternal behaviour is under some genetic control is obvious from both earlier strain comparisons and selection experiments and more contemporary studies using molecular genetics. However, the available material is too heterogenous to allow conclusions about maternal behaviour as an adaptive trait that has evolved through natural selection. Alterations of maternal behaviour in mice in which a gene has been inactivated (reviewed in Bridges, 1998) tell us that this gene is important but give little information about how natural variation in gene expression affects the behaviour. The identification of QTLs involved in regulation of maternal behaviour is interesting; however, the behaviour study in Peripato et al. (2002) is too poorly described to permit confident conclusions. Strain differences in maternal behaviour should be viewed both in the context of overall differences in behaviour (e g Crawley et al., 1997) and in the light of different ecological origins

\footnotetext{
${ }^{4}$ Data was not reported and the methodology for behaviour studies not described, so these results should be interpreted with caution.
} 
(Sluyter and van Oortmerssen, 2000). Differences in specific behavioural elements may also relate to each other. For example, Bond et al. (2002) considered the higher quality of nests in $\mathrm{C}_{57} \mathrm{BL} / 6 \mathrm{~J}$ mice against the finding that DBA/2 mothers spend more time in the nest (Brown et al., 1999) to suggest that these strains might utilize different behavioural strategies to maintain pup temperature.

\section{Other factors influencing normal maternal behaviour}

Litter size and composition as well as maternal experience also affect time spent in the nest: Priestnall (1972) found that females rearing large litters left the nest more often than females rearing small litters, and consequently spent less time on maternal behaviour, irrespective of whether food and water was available in the nest. Mendl and Paul (1990) found that females nursing mixed litters ( $1 \mathrm{M}$ $+{ }_{3}$ F) spent more time on maternal behaviours and seemed to wean litters later than females nursing all-male litters; however, pups in mixed litters grew slower, suggesting that the greater suckling time reflected high milk demand in these pups. Experience improves maternal behaviour as demonstrated by higher survival in second versus first litters in both $\mathrm{C}_{57} \mathrm{BL} / 6 \mathrm{~J}$ and DBA/2J mice, and larger weight gains in DBA/2J mice (Brown et al., 1999).

\section{Infanticide and cannibalism}

Besides taking care of the offspring and providing them with food, shelter, and warmth, house mice are reported to be infanticidal under certain circumstances. Infanticide is defined by McCarthy and vom Saal $(1985$, p. 843) as "the killing of conspecific preweaning young". Several studies have addressed infanticidal behaviour from a behavioural ecology perspective, and mice are often used as model animals in laboratory studies of infanticide (see Labov et al., 1985 for review). Elwood (1991) described two main research approaches: studies of male infanticide (see also Hrdy's sexual selection hypothesis in Section 7) and studies of inhibition of infanticide and onset of parental care.

Infanticidal tendencies differ both within and between inbred laboratory strains and wild stocks of mice (Perrigo et al., 1993), with a frequency averaging around 10\% for both outbred and inbred mice (McCarthy and vom Saal, 1985). Wild-type mice have been reported to be more likely to exhibit infanticide (Jakubowski and Terkel, 1982; McCarthy and vom Saal, 1985). There are also effects of gender and sexual experience (McCarthy et al., 1986; Soroker and Terkel, 1988; D'Amato, 1993; Perrigo et al., 1993). D'Amato (1993) reported sexually naïve males to be more infanticidal than sexually naı"ve females, and they also adopted different behavioural strategies when exposed to pups. Males killed pups indiscriminately while female mice discriminated first by familiarity to the pups, and secondly on the degree of relatedness.

McCarthy and vom Saal (1985) reported the majority of virgin and pregnant wild-type female mice to be infanticidal towards unrelated young, whereas virtually no female mice were infanticidal towards their own offspring at parturition (McCarthy, 1990). However, besides killing unrelated or unfamiliar offspring, it has been speculated that female mice sometimes also kill own offspring. There is experimental evidence of female mice reducing litter size when food is restricted (König, 1989; Elwood, 1991), and stress has been suggested to cause females to neglect, kill, or eat their young (Poley, 1974). It should be noted that what is usually found is a reduced number of pups, or partly 
eaten pups in the cage, but no evidence of females actively killing pups. Thus, maternal cannibalism may be a more appropriate term.

With a cross-fostering approach, König (1989) observed kin recognition and maternal care under restricted feeding and found that only $66 \%$ of the young survived until weaning when food was restricted. However, when killing the pups, females did not seem to discriminate between own and alien young. When examining emotionality related to maternal cannibalism, Poley (1974) found that cannibalistic females were more active under an auditory stressor and suggested that auditory disturbances might have been the initial cause of the cannibalism. Reeb-Whitaker et al. (2001) found that cage changing also affected pup survival. When comparing different frequencies of cage changing (every 7 th, $14^{\text {th }}$ and 21 st day) in ventilated cages, the number of pups born was not affected, but pup mortality was higher when cages were changed every 7 th day.

Many mutant, knockout and transgenic mice display poor maternal behaviour or complete inability to rear offspring (e.g. Gustavino, 1983; Nelson and Young, 1998; Brown et al., 1996; Alston-Mills et al., 1999; Jugloff et al., 2006). While wild-type females usually gathered their pups in a nest and crouched over them to nurse, pups of fosB mutant mice were scattered around the cage and neglected by the mother (Brown et al., 1996). Gustavino (1983) reported mothers of the mutant mouse staggerer to fail in removing the amniotic membrane, leading to pups dying from being choked, and surviving pups ignored and dying of cold or hunger. By using foster mothers and providing staggerer mothers with older pups, the survival rate was improved. However, $1 / 3$ still died and the mothers did not lick the pups, did not build a nest, never retrieved the pups and assumed a peculiar position when nursing. Alston-Mills et al. (1999) reported that the hubb/hubb mutation tended to be sensitive to disturbance of their cages, responding with infanticide and cannibalism, and also the Mecp2-deficient mouse model is difficult to rear with high incidence of infanticide (Jugloff et al., 2006).

Even though a newborn infant represents a large investment, under certain environmental conditions, maternal infanticide could result in net benefit for surviving offspring and parent (McCarthy and vom Saal, 1985; Elwood, 1991). In the laboratory environment, there is no physical risk of predation or starvation. However, population density is extremely high and humans moving about in the room may be perceived as potential predators by the mice, in particular if directly handling female and pups as when cleaning cages. Infanticide towards own offspring is described as rare (McCarthy and vom Saal, 1985), but still reported in several studies (e.g. Fuchs, 1982; CohenSalmon et al., 1985; Bond et al., 2002), even though the causal factors are seldom discussed. Disturbance of the litter or nest-site might predict decreased chance of survival of the pups and the best strategy might in this case be to cannibalize the litter and start a new litter (Elwood, 1991). Infanticide may be one factor underlying the reported variation in reproductive success in different housing conditions (e.g. Tsai et al., 2003); however, no studies have addressed the problem with maternal infanticide under normal laboratory conditions. When detailed information on the course of events is missing, instead of being seen as infanticide - the active killing of preweaning young - it might be more appropriate to refer simply to pup mortality, litter loss and maternal cannibalism. Strong evidence for infanticide as a major cause of pup mortality is lacking. 


\section{A note on standard tests and manipulation}

Ethological observations of behaviour in the animals' home environment are time consuming, and often different tests are used to measure parental behaviour. One commonly used method is to present pups of differing ages to an adult male or female mouse and measure the behavioural responses. At testing, pups are between 1 and 7 days old and placed in the home cage of the test animal. Behaviour of the test animals is measured using a series of spot checks (between 30 min and $24 \mathrm{~h}$ ), or a fixed period (from $15 \mathrm{~min}$ to $24 \mathrm{~h}$ ) after introduction of the pup. Examples of measured behaviours include parental (hovering over pup/retrieving/licking young/nest building/ warm/in nest), infanticidal (pup dead/biting/wounded), non-infanticidal (pups alive), untouched (pup cold and not in nest, neither harm nor exhibiting parental care), and neutral (only sniffing); sometimes parameters such as nursing posture, grooming pup, nest building, self-grooming, exploration and digging are also used (e.g. Jakubowski and Terkel, 1982; McCarthy and vom Saal, 1985; McCarthy et al., 1986; Soroker and Terkel, 1988; D'Amato, 1993; vom Saal et al., 1995; Ebensperger, 1998). The same approach is used to measure infanticidal tendencies, usually referred to as "screening tests" (e.g. Gandelman, 1973b,c; McCarthy and vom Saal, 1986; Perrigo et al., 1993).

It is considered to be highly characteristic for females to retrieve pups that are absent from the nest (Porter, 1983), and pup retrieval tests are used to measure maternal behaviour (see e.g. Meek et al., 2001). In this test the pups from a lactating female are placed outside the nest and latency for first retrieval, total number of pups retrieved, number of times female moved away from pup without retrieving, and total time to retrieve all pups is observed.

Some studies include experimental manipulation of litter compositions or sizes. For this purpose pups may be culled at parturition or short after (e.g. Gandelman, 1973b; Priestnall, 1973; Meek et al., 2001), or cross-fostered between females (see e.g. König, 1994; Maestripieri, 1991). During this procedure the whole litter is usually removed from the lactating female, and replaced shortly after in the new composition.

\section{General discussion}

Similar to other altricial species, the female mouse prepares a nest before parturition. Under natural conditions, mice live in social groups where both males and females may contribute to rearing offspring, and given the opportunity females nest and nurse communally. However, social living may also be risky as other adults may be infanticidal. A distinct aggressive behaviour pattern shown by pregnant and lactating female is thought to protect pups and nest against such attacks. Communication through external stimuli from the pups contributes to maintaining maternal behaviour. Maternal behaviour is influenced by both genetic and environmental factors such as stress. Under experimental conditions, with restricted access to resources, females may reduce litter size through infanticide; however, maternal cannibalism under normal laboratory conditions is poorly understood. Many of the studies included in this review use only standard tests to measure maternal behaviour. Given that detailed behaviour observations over extended periods are time consuming, this is understandable; however, it gives rise to a number of considerations. Firstly, studying only one aspect, or during brief periods (often within the light, non-active period of the day), gives a very limited understanding of normal maternal behaviour. For example, does a seemingly maladaptive maternal aggression response in stressed females (Pardon et al., 2000) reflect a disturbance in 
maternal behaviour or a difficulty in dealing with the stressful situation of an aggressive intruder? Secondly, standard tests fail to account for potential effects of housing system and physical and social testing environment (see e.g. McCarthy and vom Saal, 1986), as discussed below. Thirdly, manipulations of the animals to differing extents are inherent in the experimental approaches, but unavoidably affect the test results. As discussed by Pryce and Feldon (2003), even as little handling as the weekly husbandry procedures creates a long-lasting effect in rat pups. Many studies use much greater interventions, such as culling or cross-fostering pups, disregarding the difference between artificially created and natural variation in litter size. Mendl (1988) reported differing results in pup weight gain between females raising their own large litters and those raising experimentally enlarged litters, and Hager and Johnstone (2005) found that foster litter growth rate was greater when the foster mother had given birth to a large litter, suggesting that the ability to raise large litters is dependent on female physiology and that a female giving birth to a small litter does not have the same ability to raise a large litter.

Some of the experimental manipulations give rise to ethical concerns, including attacks and injuries in studies of infanticidal behaviour and maternal aggression, food-depriving animals or increasing litter sizes inducing stress in the females, and the prolonged exposure to cold for pups that are not able to thermoregulate (Elwood, 1991). As in other animal research, the experimental procedures can be adapted to minimize suffering; rather than using death as an endpoint the experiment can be stopped if animals are being harmed (e.g. Elwood et al., 1990; Ebensperger, 1998). Reduction of animal numbers may be possible; Elwood et al. (1990) demonstrated that a single pup was an effective stimulus for discriminating between infanticidal and non-infanticidal males in a screening test.

An additional methodological concern is the choice of subspecies. Jakubowski and Terkel (1982, p. 1033) argued that "the laboratory mouse might be a misleading model for studying parental behaviour in Mus musculus". However, using wild animals presents other difficulties: these are very sensitive to the presence of people (McCarthy and vom Saal, 1985) and probably also to the restrictive laboratory environment. That is, the large differences between wild and laboratory strains (e.g. McCarthy et al., 1986) may be at least partly due to different abilities to cope with the laboratory environment.

Maternal behaviour is a complex behaviour with many influencing factors. Housing and management routines in the laboratory animal facility do not always take these factors into consideration. Overall, the housing and husbandry practices have been designed for hygiene and standardization, with little consideration for natural behaviour, preventing animals from performing many motivated behaviours and giving them little control over their environment (e.g. The Rodent Refinement Working Party, 1998; Olsson and Dahlborn, 2002). In the case of reproducing mice, two discrepancies between natural behaviour and the cage environment seem particularly important: the social environment and the access to nesting material. Under free-living conditions with unlimited food supply, female mice nest and nurse communally and male mice exhibit paternal care. Females build nests, which are important for thermoregulation. In contrast, in many of the reviewed studies (see Table 1 in on-line supplementary material for an overview), females were housed singly in barren cages. While single female housing is the practice in many animal facilities, even within the limitations of the normal cage it is possible to take natural reproductive behaviour into account, e.g. by housing females in trios with one male and two females, and with access to nesting material. There is data indicating that housing system affects reproductive parameters. Tsai et al. (2003) found that 
access to shelters and nesting material reduced the number of pups born but not the number of pups weaned; however, few results and no detailed behaviour studies have been published.

This review is an attempt to provide a synthesized description of mouse maternal behaviour. Recognising that "maternal care does not take place in a vacuum but constitutes a complex set of dyadic interactions between dam and litter..." (Pryce and Feldon, 2003, p. 66), we want to emphasize the importance of considering the complexity of maternal behaviour and dam-infant interactions in future research. Against the background of reproduction problems in many strains in biomedical research facilities, studies of maternal behaviour in the standard animal facility conditions seem particularly pertinent.

\title{
Acknowledgements
}

We would like to thank Robert Eriksson, Bo Algers, Hanno Würbel, Dan Weary and an anonymous referee for useful comments on earlier versions of this manuscript. The work was supported by a grant from The Swedish National Board for Laboratory Animals and The Swedish Animal Welfare Agency.

\section{References}

Alcock, J., 1993. Animal Behavior: An Evolutionary Approach, 5th ed. Sinauer Associates, Inc., Sunderland, MA, USA (Chapters 1 and 3 ).

Alston-Mills, B., Parker, A.C., Eisen, E.J., Wilson, R., Fletcher, S., 1999. Factors influencing maternal behaviour in the hubb/hubb mutant mouse. Physiol. Behav. 68, 3-8.

Anisman, H., Zaharia, M.D., Meaney, M.J., Meralis, Z., 1998. Do early-life events permanently alter behavioural and hormonal responses to stressors? Int. J. Dev. Neurosci. 16, 149-164.

Baumans, V., 2004. The welfare of laboratory mice. In: Kaliste, E. (Ed.), The Welfare of Laboratory Animals. Kluwer Academic Publishers, The Netherlands, pp. 119-152.

\author{
.
}


Berry, R.J., 1970. The natural history of the house mouse. Fld Stud. 3, 219-262.

Blaffer Hrdy, S., 1979. Infanticide among animals: a review, classification, and examination of the implications for the reproductive strategies of females. Ethol. Sociobiol. 1, 13-40.

Bond, T.L.Y., Neumann, P.E., Mathieson, W.B., Brown, R.E., 2002. Nest building in nulligravid, primigravid and primiparous $\mathrm{C}_{57} \mathrm{BL} / 6 \mathrm{~J}$ and DBA/2J mice (Mus musculus). Physiol. Behav. 75, 551-555.

Bourke, A.F.G., 2001. Sociality and kin selection in insects. In: Krebs, J.R., Davies, N.B. (Eds.), Behavioural Ecology: An Evolutionary Approach. Blackwell Science Ltd., UK, (Chapter 9), pp. 203227.

Branchi, I., Santucci, D., Vitale, A., Alleva, E., 1998. Ultrasonic vocalizations by infant laboratory mice: a preliminary spectrographic characterization under different conditions. Dev. Psychobiol. 33, 249256.

Bridges, R.S., 1998. The genetics of motherhood. Nat. Genet. 20, 108-109.

Broida, J., Svare, B., 1982a. Postpartum aggression in $\mathrm{C}_{57} \mathrm{BL} / 6 \mathrm{~J}$ and DBA/2J mice: experimental and environmental influences. Behav. Neural Biol. 35, 76-83.

Broida, J., Svare, B., 1982b. Strain-typical patterns of pregnancy-induced nest building in mice: maternal and experiential influences. Physiol. Behav. 29, 153-157.

Broida, J., Svare, B., 1983. Mice: progesterone and the regulation of strain differences in pregnancyinduced nest building. Behav. Neurosci. 6, 994-1004.

Bronson, F.H., 1979. The reproductive ecology of the house mouse. Quart. Rev. Biol. 54, 265-299.

Bronson, F.H., Dagg, C.P., Snell, G.D., 1966. Reproduction. In: Green, E.L. (Ed.), Biology of the Laboratory Mouse. McGraw-Hill, New York, pp. 187-204.

Brown, J.R., Ye, H., Bronson, R.T., Dikkes, P., Greenberg, M.E., 1996. A defect in nurturing in mice lacking the immediate early gene fosB. Cell 86, 279-309.

Brown, R.E., Mathieson, B., Stapleton, J., Neumann, P.E., 1999. Maternal behavior in female C57BL/6J and DBA/2J female mice. Physiol. Behav. 67, 599-605.

Bruce, H.M., 1961. Time relations in the pregnancy-block induced in mice by strange males. J. Reprod. Fertil. 2, 138-142.

Brudzynski, S.M., 2005. Principles of rat communication: quantitative parameters of ultrasonic calls in rats. Behav. Genet. 35, 85-92.

Bult, A., Lynch, C.B., 1997. Nesting and fitness: lifetime reproductive success in house mice bidirectionally selected for thermoregulatory nest-building behaviour. Behav. Genet. 27, 231-240. 
Busnel, R.G., Lehmann, A., 1977. Acoustic signals in mouse maternal behaviour: retrieving and cannibalism. Z. Tierpsychol. 45, 321-324.

Causey, D., Waters, R.H., 1936. Parental care in mammals with especial reference to the carrying of young by the albino rat. J. Comp. Psychol. 22, 241-254.

Cohen-Salmon, C., 1988. What role does sensory perception play in the onset and maintenance of pup care behavior in laboratory rodents? Eur. Bull. Cogn. Psychol. 8, 53-94.

Cohen-Salmon, C., Garlier, M., Roubertoux, P., Jouhaneau, J., Semal, C., Paillette, M., 1985. Differences in patterns of pup care in mice $\mathrm{V}$-pup ultrasonic emissions and pup care behavior. Physiol. Behav. 35, 167-174.

Crawley, J.N., Belknap, J.K., Collins, A., Crabbe, J.C., Frankel, W., Henderson, N., Hitzemann, R.J., Maxson, S.C., Miner, L.L., Silva, A.J., Wehner, J.M., Wynshaw-Boris, A., Paylor, R., 1997. Behavioral phenotypes of inbred mouse strains: implications and recommendations for molecular studies. Psychopharmacology 132 (2), 107-124.

D'Amato, F.R., 1993. Effect of familiarity with the mother and kinship on infanticidal and alloparental behaviour in virgin house mice. Behaviour 124, 313-326.

D'Amato, F.R., Cabib, S., Ventura, R., Orsini, C., 1998. Long-term effects of postnatal manipulations are prevented by maternal anxiolytic treatment in mice. Dev. Psychobiol. 32, 225-234.

D'Amato, F.R., Scalera, E., Sarli, C., Moles, A., 2005. Pups call, mothers rush: does maternal responsiveness affect the amount of ultrasonic vocalizations in mouse pups? Behav. Genet. 35, 103112.

Dawkins, M.S., 1990. From an animal's point of view: motivation, fitness and animal welfare. Behav. Brain Sci. 13, 1-61.

Dawkins, M.S., 1998. Evolution and animal welfare. Quart. Rev. Biol. 73, 305-328. Ebensperger, L.A., 1998. The potential effects of protected nests and cage complexity on maternal aggression in house mice. Aggressive Behav. 24, 385-396.

Ehret, G., 2005. Infant rodent communication-a gate to the understanding of sound communication. Behav. Genet. 35, 19-29.

Ehret, G., Bernecker, C., 1986. Low-frequency sound communication by mouse pups (Mus musculus): wriggling calls release maternal behaviour. Anim. Behav. 34, 821-830.

Elwood, R.W., 1983. Paternal care in rodents. In: Elwood, R.W. (Ed.), Parental Behaviour of Rodents. John Wiley \& Sons Ltd., pp. 235-257.

Elwood, R.W., 1991. Ethical implications of studies on infanticide and maternal aggression in rodents. Anim. Behav. 42, 841-849. 
Elwood, R.W., McCauley, P.J., 1983. Communication in rodents: infants to adults. In: Elwood, R.W. (Ed.), Parental Behaviour of Rodents. John Wiley \& Sons Ltd., pp. 127-149.

Elwood, R.W., Nesbitt, A.A., Kennedy, H.F., 1990. Maternal aggression in response to the risk of infanticide by male mice, Mus domesticus. Anim. Behav. 40, 1080-1086.

Emlen, S.T., 2001. Predicting family dynamics in social vertebrates. In: Krebs, J.R., Davies, N.B. (Eds.), Behavioural Ecology: An Evolutionary Approach. Blackwell Science Ltd., UK, (Chapter 10), pp. 228253 .

Ewer, R.F., 1968. Ethology of Mammals. Logos Press Limited, London (Chapter 10), pp. 234-285. Fuchs, S., 1981. Consequences of premature weaning on the reproduction of mothers and offspring in laboratory mice. Z. Tierpsychol. 55, 19-32.

Fuchs, S., 1982. Optimality of parental investment: the influence of nursing on reproductive sucess of mother and female young house mice. Behav. Ecol. Sociobiol. 10, 39-51.

Gandelman, R., 1973a. Induction of maternal nest building in virgin female mice by the presentation of young. Horm. Behav. 4, 191-197.

Gandelman, R., 1973b. The ontogeny on maternal responsiveness in female Rockland-Swiss albino mice. Horm. Behav. 4, 257-268.

Gandelman, R., 1973c. The development of cannibalism in male Rockland-Swiss mice and the influence of olfactory bulb removal. Dev. Psychobiol. 6, 159-164.

Gustavino, J.-M., 1983. Environmental features determining successful rearing in the mutant mouse Staggerer. Physiol. Behav. 32, 225-228.

Hager, R., Johnstone, R.A., 2003. The genetic basis of family conflict resolution in mice. Nature 421, 533-535.

Hager, R., Johnstone, R.A., 2005. Differential growth of own and alien pups in mixed litters of mice: a role for genomic imprinting? Ethology $111,705-714$.

Hahn, M.E., Lavooy, M.J., 2005. A review of the methods of studies on infant ultrasound production and maternal retrieval in small rodents. Behav. Genet. $35,31-52$.

Hayes, L.D., 2000. To nest communally or not to nest communally: a review of rodent communal nesting and nursing. Anim. Behav. 59, 677-688.

Hennessy, M.B., Li, J., Lowe, E.L., Levine, S., 1980. Maternal behavior, pup vocalizations, and pup temperature changes following handling in mice of 2 inbred strains. Dev. Psychobiol. 13, 573-584.

Hood, K.E., Dreschel, N.A., Granger, D.A., 2003. Maternal behaviour changes after immune challenge of neonates with developmental effects on adult social behaviour. Dev. Psychobiol. 42, 17-34. 
Iturrian, W.B., Fink, G.B., 1968. Comparison of bedding material: habitat preference of pregnant mice and reproductive performance. Lab. Anim. Care 18, 160-164.

Jakubowski, M., Terkel, J., 1982. Infanticide and caretaking in non-lactating Mus musculus: influence of genotype, family group and sex. Anim. Behav. 30, 1029-1035.

Jensen, P., 1993. Djurens beteende och orsakerna till det. LTs fo“rlag, Stockholm.

Jugloff, D.G.M., Logan, R., Eubanks, J.H., 2006. Breeding and maintenance of an Mecp2-deficient mouse model of Rett syndrome. J. Neurosci. Meth. 154, 89-95.

König,B.,1989.Kinrecognitionandmaternalcareunderrestrictedfeeding

inhousemice(Mus domesticus). Ethology 82, 328-343.

König, B., 1993. Maternal investment of communally nursing female house mice (Mus musculus domesticus). Behav. Process. 30, 61-74.

König, B., 1994. Fitness effects of communal rearing in house mice: the role of relatedness versus familiarity. Anim. Behav. 48, 1449-1457.

König, B., Markl, H., 1987. Maternal care in house mice. Behav. Ecol. Sociobiol. 20, 1-9.

Labov, J.B., Huck, U.W., Elwood, R.W., Brooks, R.J., 1985. Current problems in the study of infanticidal behaviour in rodents. Quart. Rev. Biol. 60, 1-20.

Latham, N., Mason, G., 2004. From house mouse to mouse house: the behavioural biology of freeliving Mus musculus and its implications in the laboratory. Appl. Anim. Behav. 86, 261-289.

Lay Jr., D.C., 2000. Consequences of stress during development. In: Moberg, G.P., Mench, J.A. (Eds.), The Biology of Animal Stress, Basic Principles and Implications for Animal Welfare. CABI Publishing, UK, (Chapter 12), pp. 249-267.

Lee, C.T., 1973. Genetic analyses of nest-building behavior in laboratory mice (Mus musculus). Behav. Genet. 3, 247- 256 .

Lee, M.H.S., Williams, D.I., 1974. Changes in licking behaviour of rat mother following handling of young. Anim. Behav. 22, 679-681.

Lisk, R.D., 1971. Oestrogen and progesterone synergism and elicitation of maternal nest-building in the mouse (Mus musculus). Anim. Behav. 19, 606-610.

Lisk, R.D., Pretlow III, R.A., Friedman, S.T., 1969. Hormonal stimulation necessary for elicitation of maternal nest-building in the mouse (Mus musculus). Anim. Behav. 17, 730-737.

Lonstein, J.S., Gammie, S.C., 2002. Sensory, hormonal and neural control of maternal aggression in laboratory rodents. Neurosci. Biobehav. Rev. 26, 869-888. 
Lynch, C.B., 1981. Genetic correlation between two types of nesting in Mus musculus: direct and indirect selection. Behav. Genet. 11, 267-272.

Lynch, C.B., Possidente Jr., B.P., 1978. Relationships of maternal nesting to thermoregulatory nesting in house mice (Mus musculus) at warm and cold temperatures. Anim. Behav. 26, 1136-1143.

Macri, S., Würbel, H., 2006. Developmental plasticity of HPA and fear responses in rats: a critical review of the maternal mediation hypothesis. Horm. Behav. 50, 667-680.

Macri, S., Würbel, H., 2007. Effects of variation in postnatal maternal environment on maternal behaviour and fear and stress responses in rats. Anim. Behav. 73, 171-184.

Macrı, S., Mason, G.J., Würbel, H., 2004. Dissociation in the effects of neonatal maternal separations on maternal care and the offspring's HPA and fear responses in rats. Eur. J. Neurosci. 20, 1017-1024.

Maestripieri, D., 1991. Litter gender composition, food availability, and maternal defence of the young in house mice (Mus domesticus). Behaviour 116, 239-251.

Maestripieri, D., Alleva, E., 1990. Maternal aggression and litter size in the female house mouse. Ethology 84, 27-34.

Mandillo, S., D'Amato, F.R., 1997. Effect of strange male odour on parental care in lactating female mice. Anim. Behav. 54, 901-910.

Manning, A., Dawkins, M.S., 1998. An Introduction to Animal Behaviour, 5th ed. Cambridge University Press, UK, pp. 133 and 234.

Manning, C.J., Dewsbury, D.A., Wakeland, E.K., Potts, W.K., 1995. Communal nesting and communal nursing in house mice, Mus musculus domesticus. Anim. Behav. 50, 741-751.

Mason, W.A., 2000. Early developmental influences of experience on behaviour, temperament and stress. In: Moberg, G.P., Mench, J.A. (Eds.), The Biology of Animal Stress, Basic Principles and Implications for Animal Welfare. CABI Publishing, UK, (Chapter 13), pp. 269-290.

McCarthy, M.M., 1990. Oxytocin inhibits infanticide in female house mice (Mus domesticus). Horm. Behav. 24, 365-375.

McCarthy, M.M., vom Saal, F.S., 1985. The influence of reproductive state on infanticide by wild female house mice (Mus musculus). Physiol. Behav. 35, 843-849.

McCarthy, M.M., vom Saal, F.S., 1986. Infanticide by virgin CF-1 and wild male house mice (Mus musculus): effects of age, prolonged isolation, and testing procedure. Dev. Psychobiol. 19, 279-290.

McCarthy, M.M., Bare, J.E., vom Saal, F.S., 1986. Infanticide and parental behavior in wild female house mice: effects of ovariectomy, adrenalectomy and administration of oxytocin and prostaglandin F2a. Physiol. Behav. 36, 17-23. 
McRae, S.B., 1996. Family values: costs and benefits of communal nesting in the moorhen. Anim. Behav. 52, 225-245.

Meek, L.R., Dittel, P.L., Sheehan, M.C., Chan, J.Y., Kjolhaug, S.R., 2001. Effects of stress during stress on maternal behavior in mice. Physiol. Behav. 72, 473-479.

Mendl, M., 1988. The effects of litter size variation on mother-offspring relationships and behavioural and physical development in several mammalian species (principally rodents). J. Zool. 215, 15-34.

Mendl, M., Paul, E.S., 1990. Litter composition affects parental care, offspring growth and the development of aggressive behaviour in wild house mice. Behaviour 116, 90-108.

Moles, A., Rizzi, R., D'Amato, F.R., 2004. Postnatal stress in mice: does "stressing" the mother have the same effect as "stressing" the pups? Dev. Psychobiol. 44, 230-237.

Morton, D.B., 2002. Behaviour of rabbits and rodents. In: Jensen, P. (Ed.), The Ethology of Domestic Animals: An Introductory Text. CABI Publishing, Wallingford, UK, (Chapter 13), pp. 193-209.

Nelson, R.J., Young, K.A., 1998. Behavior in mice with targeted disruption of single genes. Neurosci. Biobehav. Rev. 453-462.

Noirot, E., 1972. Ultrasounds and maternal behavior in small rodents. Dev. Psychobiol. 5, 371-387.

Noirot, E., 1974. Nest-building by the virgin female mouse exposed to unltrasound from inaccessible pups. Anim. Behav. 22, 410-420.

Olsson, I.A.S., Dahlborn, K., 2002. Improving housing conditions for laboratory mice: a review of 'environmental enrichment'. Lab. Anim. 36, 243-270.

Ostermeyer, M.C., 1981. The parental behaviour of the house mouse, Mus musculus L. Ph.D. Thesis. The Queen's University, Belfast. 
Ostermeyer, M.C., 1983. Maternal aggression. In: Elwood, R.W. (Ed.), Parental Behaviour of Rodents. John Wiley and Sons Ltd., Chichester, pp. 151-179.

Packer, C., Lewis, S., Pusey, A., 1992. A comparative analysis of non-offspring nursing. Anim. Behav. $43,265-281$.

Pardon, M.-C., Ge'rardine, P., Joubert, C., Pe'rez-Diaz, F., Cohen-Salmon, S., 2000. Influence of prepartum chronic ultramild stress on maternal pup care behaviour in mice. Biol. Psychiat. $47,858-$ 863.

Paul, L., Gronek, J., Politch, J., 1980. Maternal aggression in mice: protection of young is a by-product of attacks at the home site. Aggressive Behav. 6, 19-29.

Peripato, A.C., de Brito, R.A., Vaughn, T.T., Pletscher, S., Matioli, S.R., Cheverud, J.M., 2002. Quantitative trait loci for maternal performance for offspring survival in mice. Genetics 162, 13411353.

Perrigo, G., Belvin, L., Quindry, P., Kadir, T., Becker, J., van Look, C., Niewoehner, J., vom Saal, F.S., 1993. Genetic mediation of infanticide and parental behaviour in male and female domestic and wild stock house mice. Behav. Genet. 23, 525-531.

Poley, W., 1974. Emotionality related to maternal cannibalism in BALB and C57BL mice. Anim. Learn. Behav. 2, 241- 244 .

Porter, R.H., 1983. Communication in rodents: adults to infants. In: Elwood, R.W. (Ed.), Parental Behaviour of Rodents. John Wiley \& Sons Ltd., pp. 95-125.

Priestnall, R., 1972. Effects of litter size on the behaviour of lactating female mice (Mus musculus). Anim. Behav. 20, 386-394.

Priestnall, R., 1973. Effects of handling on maternal behaviour in the mouse (Mus musculus): an observational study. Anim. Behav. 21, 383-386.

Pryce, C.R., Feldon, J., 2003. Long-term neurobehavioural impact of the postnatal environment in rats: manipulations, effects and mediating mechanisms. Neurosci. Biobehav. Rev. 27, 57-71.

Reeb-Whitaker, C.K., Paigen, B., Beamer, W.G., Bronson, R.T., Churchill, G.A., Chweizer, I.B., Myers, D.D., 2001. The impact of reduced frequency of cage changes on the health of mice housed in ventilated cages. Lab. Anim. 35, 58-73.

Refining Rodent husbandry: the mouse, 1998. Report of the rodent refinement working party. Jennings, M., Batchelor, G.R., Brain, P.F., Dick, A., Elliott. H., Francis. R.J., Hubrecht, R.C., Hurst, J.L., Morton, D.B., Peters, A.G., Raymond, R., Sales, G.D., Sherwin, C.M., West, C. Lab. Anim. 32, 233259 .

Rules and Guidelines for Nomenclature of Mouse and Rat Strains: http://www.informatics.jax.org/mgihome/nomen/strains.shtml. 
Sayler, A., Salmon, M., 1969. Communal nursing in mice: influence of multiple mothers on the growth of the young. Science 164, 1309-1310.

Sayler, A., Salmon, M., 1971. An ethological analysis of communal nursing by the house mouse (Mus musculus). Behaviour XL 62, 60-85.

Schneider, J.E., Lynch, C.B., 1984. Investigation of a common physiological mechanism underlying progesterone-induced and maternal nesting in mice, Mus musculus. J. Comp. Psychol. 98, 165-176. Schneider, J.E., Lynch, C.B., Possidente, B., Hegmann, J.P., 1982. Genetic association between progesterone-induced and maternal nesting in mice. Physiol. Behav. 29, 97-105.

Sherrod, K.B., Connor, W.H., Meier, G.W., 1974. Transient and enduring effects of handling on infant and maternal behaviour in mice. Dev. Psychobiol. 7, 31-37.

Silver, L.M., 1995. Mouse Genetics: Concepts and Applications. Oxford University Press, Oxford.

Sluyter, F., van Oortmerssen, G.A., 2000. A mouse is not just a mouse. Anim. Welfare 9, 193-205. Soroker, V., Terkel, J., 1988. Changes in incidence of infanticidal and parental responses during reproductive cycle in male and female wild mice Mus musculus. Anim. Behav. 36, 1275-1281.

Tsai, P.-P., Oppermann, D., Stelzer, H.D., Ma“hler, M., Hackbarth, H., 2003. The effects of different rack systems on the breeding performance of DBA/2 mice. Lab. Anim. 37, 44-53.

vom Saal, F.S., Franks, P., Boechler, M., Palanza, P., Parmigiani, S., 1995. Nest defence and survival of offspring in highly aggressive wild Canadian female house mice. Physiol. Behav. 58, 669-678.

Walker, E.P., Nowak, R.M., 1999. Walker's Mammals of the World, 6th ed., vol. II. John Hopkins University Press, Baltimore.

Wallace, M.E., 1981. The breeding, inbreeding and management of wild mice. Symp. Zool. Soc. Lond. 47, 183-204.

Wilkinson, G.S., Baker, A.E.M., 1988. Communal nesting among genetically similar house mice. Ethology 77, 103-114.

Williams, E., Scott, J.P., 1953. The development of social behaviour patterns in the mouse, in relation to natural periods. Behaviour VI 35-67.

Willner, P., 1997. Validity, reliability and utility of the chronic mild stress model of depression: a 10year review and evaluation. Psychopharmacology 134, 319-329.

Wolff, J.O., Peterson, J.A., 1998. An offspring-defense hypothesis for territoriality in female mammals. Ethol. Ecol. Evol. 10, 227-239.

Wright, S.L., Brown, R.E., 2000. Maternal behavior, paternal behavior, and pup survival in CD-1 albino mice (Mus musculus) in three different housing conditions. J. Comp. Psychol. 114, 183-192. 
Table 1. Housing conditions and strains used in the reviewed studies

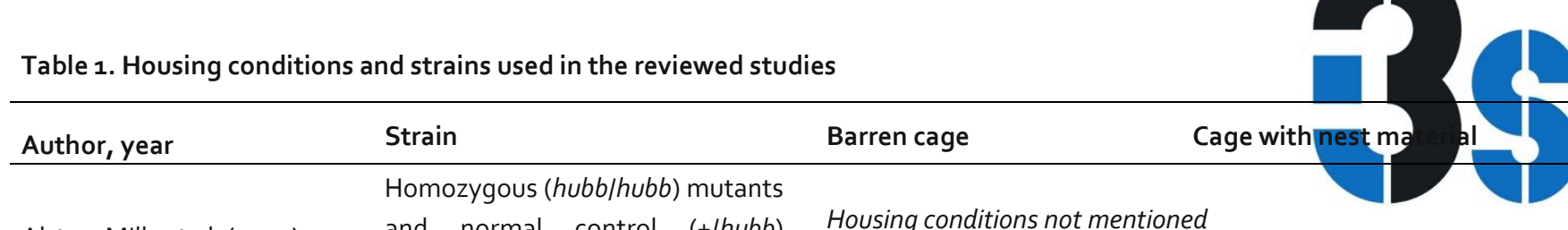

Alston-Mills et al. (1999) and normal control (+/hubb) Housing conditions not mentioned siblings.

\begin{tabular}{ll} 
C57BL/6J and DBA, descendants \\
Bond et al. (2002) & (The Jackson Laboratory) \\
\hline
\end{tabular}

$28 \times 12 \times 16 \mathrm{~cm}$ Plexiglas cages,

microbarrier tops, $300 \pm 10 \mathrm{ml}$ Pro-

chip shavings for bedding material,

$240 \pm 10 \mathrm{ml}$ pine shavings as nesting

material.

\begin{tabular}{|c|c|c|c|}
\hline \\
\hline Branchi et al. (1998) & $\begin{array}{l}\text { Outbred Swiss-derived strain: CD- } \\
1\end{array}$ & $\begin{array}{l}42 \times 27 \times 14 \mathrm{~cm} \text { Plexiglas } \\
\text { boxes (home cages). } \\
\text { Breeding pairs: housed in } \\
33 \times 13 \times 14 \mathrm{~cm} \text { boxes. }\end{array}$ & \\
\hline Broida and Svare (1982a) & $\begin{array}{l}\mathrm{C}_{57} \mathrm{BL} / 6 \mathrm{~J} \text { and } \mathrm{DBA} / 2 \mathrm{~J} \text { originally } \\
\text { purchased from Jackson } \\
\text { Laboratory, Maine. }\end{array}$ & $\begin{array}{l}19 \times 29 \times 13 \mathrm{~cm} \text { translucent } \\
\text { polypropylene cages, wood } \\
\text { shavings on the floor. }\end{array}$ & \\
\hline Broida and Svare (1982b) & 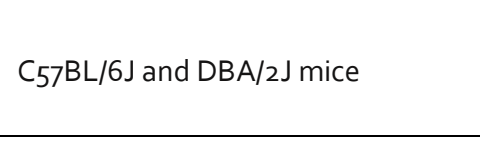 & 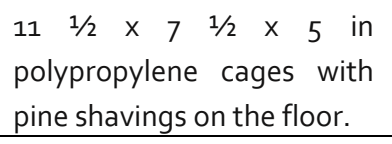 & $\begin{array}{l}\text { Absorbent cotton provided day o } \\
\text { of pregnancy }\end{array}$ \\
\hline Broida and Svare (1983) & $\mathrm{C}_{57} \mathrm{BL} / 6 \mathrm{~J}$ and $\mathrm{DBA} / 2 \mathrm{~J}$ mice & $\begin{array}{l}29.2 \times 19 \times 12.7 \quad \mathrm{~cm} \\
\text { polypropylene cages with } \\
\text { pine shavings on the floor }\end{array}$ & $\begin{array}{l}\text { For virgin and pregnant females: } \\
\text { preweighed amount of absorbent } \\
\text { cotton. } \\
\text { Animals tested during lactation: } \\
\text { received cotton for the first time } \\
12 \mathrm{hr} \text { following parturition. }\end{array}$ \\
\hline Brown et al. (1999) & $\mathrm{C}_{57} \mathrm{BL} / 6 \mathrm{~J}$ and $\mathrm{DBA} / 2 \mathrm{~J}$ & & $\begin{array}{l}28 \times 12 \times 16 \mathrm{~cm} \text { Plexiglas cages, } \\
\text { Micro-Barrier tops. Floor lined with } \\
\text { Pro-Chip shavings, sterilized pine } \\
\text { shaving for nest material. }\end{array}$ \\
\hline
\end{tabular}


Table 1. Housing conditions and strains used in the reviewed studies

\begin{tabular}{|c|c|c|c|c|}
\hline Author, year & Strain & Barren cage & Cage with nest $\mathrm{ma}$ & Complex cages structure / Furnished \\
\hline Bult and Lynch (1997) & $\begin{array}{l}\text { Mus domesticus selected for high } \\
\text { and low nest building behaviour. }\end{array}$ & & $\begin{array}{l}\text { Access to } 10 \mathrm{~g} \text { of cotton, new } \\
\text { cotton every } 5 \text { days when cages } \\
\text { where changed. }\end{array}$ & \\
\hline Cohen-Salmon et al. (1985) & $\begin{array}{l}\text { Strains: NZB, XLII, A/J, DBA/2, } \\
\mathrm{C}_{57 \mathrm{Br}}, \mathrm{BALB} / \mathrm{C}, \mathrm{CBA} / \mathrm{H}, \mathrm{C} 57 \mathrm{BL} / 6\end{array}$ & Besides cage floor (sawdust) no & t mentioned & \\
\hline D'Amato (1993) & $\begin{array}{l}\text { Swiss-Webster albino mice } \\
\text { (Plaisant, Italy) }\end{array}$ & $\begin{array}{l}\text { Females around delivery: } \\
\text { Plexiglas cages ( } 30 \times 13 \times 13 \\
\mathrm{~cm}) \text {, wood chips on floor; } \\
\text { subjects group housed: } \\
\text { Plexiglas cages }(27 \times 15 \times 26 \\
\mathrm{cm}) \text {. } \\
\text { Experimental cage: } \\
30 \times 13 \times 13 \mathrm{~cm} \text { cage. }\end{array}$ & & \\
\hline D'Amato et al. (1998) & $\begin{array}{l}\text { Outbred albino mice (Plaisant, } \\
\text { Italy) }\end{array}$ & $\begin{array}{l}33 \times 15 \times 13 \mathrm{~cm} \text { Plexiglas } \\
\text { cages, floor covered with } \\
\text { sawdust. }\end{array}$ & & \\
\hline D'Amato et al. (2005) & $\begin{array}{l}\text { Experiment 1: NMRI mice } \\
\text { Experiment 2: male and female } \\
\mathrm{C}_{57 \mathrm{BL} / 6 \text { and outbred albino } \mathrm{NMRl} ;} \\
\text { male BALB/C; }\end{array}$ & $\begin{array}{l}\text { Exp. } 1 \text { and } 2: \text { when } \\
\text { pregnancy detected } \\
33 \times 13 \times 13 \mathrm{~cm} \text { cages with } \\
\text { bedding. }\end{array}$ & & \\
\hline
\end{tabular}

$50 \times 25 \times 29 \mathrm{~cm}$ tanks, clear Plexiglas, wood shavings. Nest present or absent.

Nest: cube shaped box $(8 \times 8 \times 8 \mathrm{~cm})$ of clear Plexiglas with tunnel $(5 \mathrm{~cm}$ long, $4.5 \mathrm{~cm}$ diameter). Nest partly filled with wood shavings.

Two-cage system: additional partitioning with square perforation $(7.5 \times 7.5 \mathrm{~cm})$ 
Table 1. Housing conditions and strains used in the reviewed studies

\begin{tabular}{|c|c|c|c|}
\hline Author, year & Strain & Barren cage & Complex cages structure / Furnished \\
\hline Ehret and Bernecker (1986) & $\begin{array}{l}\text { Outbred NMRI (Mus musculus) } \\
\text { mice }\end{array}$ & $\begin{array}{l}\text { Standard cages }(26.5 \times 20 \times 14 \\
\mathrm{cm})\end{array}$ & \\
\hline Elwood et al. (1990) & $\mathrm{CS}_{1}$ & $\begin{array}{l}\text { After weaning: } 40 \times 24 \times 12 \mathrm{~cm} \\
\text { cages, wood shavings as } \\
\text { cage litter. Test cage: } \\
30 \times 13 \times 12 \mathrm{~cm} \text {. Housing } \\
\text { condition around mating } \\
\text { and parturition not } \\
\text { mentioned. }\end{array}$ & \\
\hline
\end{tabular}

\begin{tabular}{|c|c|c|}
\hline Fuchs (1981) & Outbred strain of laboratory mice. & $\begin{array}{l}\text { Makrolon cages }(0.55 \times 0.33 \\
\mathrm{m}^{2} \text { ) }\end{array}$ \\
\hline
\end{tabular}

Fuchs (1982) $\quad \begin{aligned} & \text { Descendants of three pairs of mice } \\ & \text { originated from unspecified strains }\end{aligned}$

Makrolon cages $\left(0.55 \times 0.33 \mathrm{~m}^{2}\right)$,

bottom covered with wood

shavings, paper as nesting

material.

\begin{tabular}{|c|c|c|c|}
\hline Gandelman (1973a) & $\begin{array}{l}\text { Outbred, heterozygotic Rockland- } \\
\text { Swiss albino mice. }\end{array}$ & $\begin{array}{l}\text { Translucent cages ( } 11 \times 7 \times 5 \\
\mathrm{~cm}) \text {, floors covered with } \\
\text { wood shavings. }\end{array}$ & \\
\hline Gandelman (1973b) & $\begin{array}{l}\text { Male Rockland-Swiss albino mice } \\
\text { (Mus musculus) }\end{array}$ & $\begin{array}{l}\text { Translucent } \quad \begin{array}{l}\text { cages } \\
(28 \times 18 \times 13 \quad \mathrm{~cm}), \quad \text { floors } \\
\text { covered with wood shavings }\end{array}\end{array}$ & \\
\hline Gandelman (1973c) & $\begin{array}{l}\text { Rockland-Swiss albino mice (Mus } \\
\text { musculus) }\end{array}$ & $\begin{array}{l}\text { Translucent cages } \\
(28 \times 18 \times 13 \quad \mathrm{~cm}), \quad \text { floors } \\
\text { covered with wood shavings }\end{array}$ & \\
\hline Gustavino (1984) & Mutant mice of $\mathrm{C}_{57} \mathrm{BL} / 6$ strain & $\begin{array}{l}\text { Standard cages }(35 \times 35 \times 20 \\
\mathrm{cm}) \text {. } \\
\text { One week before delivery: } \\
\text { pregnant females placed in } \\
10 \times 20 \times 10 \mathrm{~cm} \text { cages. }\end{array}$ & $\begin{array}{l}\text { Experimental apparatus: } \\
\text { Box used for constraining mother with pups: } 9 \mathrm{~cm} \text { in } \\
\text { diameter, height } 5 \mathrm{~cm} \text {. Floor of fine-meshed cloth, holes in } \\
\text { the cover of the box. }\end{array}$ \\
\hline Hager and Johnstone (2003) & $\mathrm{CBA}$ and $\mathrm{C}_{57 / \mathrm{B} 6}$ mice. & Housing conditions not mentioned & \\
\hline
\end{tabular}


Table 1. Housing conditions and strains used in the reviewed studies

\begin{tabular}{|c|c|c|}
\hline Author, year & Strain & Barren cage \\
\hline Hennessy et al. (1980) & $\begin{array}{l}\text { C57BL/6J and } \mathrm{A} / \mathrm{J} \text { mice (Mus } \\
\text { musculus), Jackson Memorial } \\
\text { Laboratories, Maine }\end{array}$ & $\begin{array}{l}\text { Clear plastic cages } \\
(28.4 \times 17.8 \times 13.3 \mathrm{~cm}) \text { lined } \\
\text { with wood shavings }\end{array}$ \\
\hline Hood et al. (2003) & $\begin{array}{l}\text { Outbred ICR albino mice (in the } \\
\text { study, selectively bred lines were } \\
\text { used) }\end{array}$ & $\begin{array}{l}\text { Reared and housed in } \\
\text { polycarbonate } \text { cages } \\
(28 \times 18 \times 13 \mathrm{~cm}) .\end{array}$ \\
\hline
\end{tabular}

Econo-cage \#21, wire mesh lid

\#22D (Maryland Plastics, N.Y.),

Wildtype house mice (Mus

musculus) that were $\mathrm{F}_{1}-\mathrm{F}_{4}$

Jakubowski and Terkel offspring of individuals trapped in

(1982) field (Israel), and $C_{57} \mathrm{BL}$ strain (originally from Israel)

Animals derived from female Individually ventilated and

$\mathrm{Mecp}_{2}{ }^{+-}$mice, all crossed with filtered home microisolator

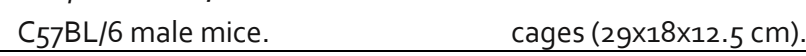

\begin{tabular}{ll} 
Jugloff et al. (2006) & Mecp2 \\
& $C_{57} \mathrm{BL} / 6$ male mice. \\
\hline & F1 generation of wild caught house
\end{tabular}

\begin{tabular}{ll} 
König and Markl (1987) & mice (Mus musculus), Germany \\
\hline F1 generation of wild caught houce
\end{tabular}

König (1989) mice (Mus domesticus)

$F_{1}$ and $F_{2}$ generation of wild

caught house mice $(M . m$. domesticus)

König (1993)

$(22 \times 16 \times 14)$

littered with commercial

deodorized cellulose bedding

material. Masking tape placed

around top of the cage to make it

darker. Newspaper as nesting

material.

Cage for observation of nest building:

3 cages joined together by plastic passageways, center cage no bedding material. One cage cellulose bedding, one flake wood (washed, dried, sized, dustless sawdust flakes).

Monogamous: single cage

$(22 \times 16 \times 14)$
For behavioual studies: four cages $(22 \times 16 \times 14 \mathrm{~cm})$ linked end to-end by tubes.

Four Macrolon cages $(22 \times 16 \times 14 \mathrm{~cm})$ linked end-to-end by tubes, all cages bedding material.

Plastig cages $(34 \times 28 \times 15 \mathrm{~cm})$ with wire mesh lids. Wild mice provided with wood shavings, and an inverted clay pot as shelter.

Polygynous: two cages (22×16×14) linked by a tube. 
Table 1. Housing conditions and strains used in the reviewed studies

\begin{tabular}{|c|c|c|c|c|}
\hline Author, year & Strain & Barren cage & Cage with nest ma & Complex cages structure / Furnished \\
\hline König (1994) & $\begin{array}{l}\text { First and second filial generation of } \\
\text { wild-caught house mice. }\end{array}$ & & & 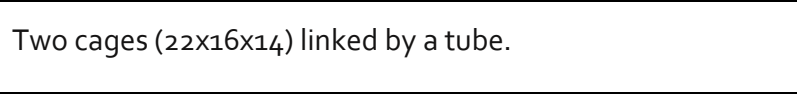 \\
\hline König and Markl (1987) & $\begin{array}{l}\text { F1 generation of wild caught house } \\
\text { mice (Mus domesticus) }\end{array}$ & & & Four cages $(22 \times 16 \times 14 \mathrm{~cm}$ ) linked by end-to-end tubes. \\
\hline Lisk (1971) & See Lisk et al. (1969) & & & \\
\hline Lisk et al. (1969) & Not mentioned & & $\begin{array}{l}40 \times 20 \times 10 \mathrm{~cm} \text { cage with wire top. } \\
60-70 \mathrm{~g} \text { of 'salt' hay provided from } \\
\text { cone from wire top. }\end{array}$ & \\
\hline $\begin{array}{l}\text { Lynch and Possidente } \\
\text { (1978) }\end{array}$ & $\begin{array}{l}\text { Lines of mice (from outbred stock } \\
\text { HS/lbg) selected for } \\
\text { thermoregulatory nestbuilding }\end{array}$ & & $\begin{array}{l}\text { Polypropylene cages, } 500 \mathrm{~cm}^{3} \\
\text { wood chip bedding. Provided with } \\
\text { cotton batting in the food hopper } \\
\text { of the cage lid. }\end{array}$ & \\
\hline Maestripieri (1991) & $\begin{array}{l}\text { Outbred Swiss mice, Charles River } \\
\text { Italia }\end{array}$ & $\begin{array}{l}\text { Opaque Plexiglas cages } \\
(33 \times 13 \times 14 \mathrm{~cm}) \text { covered with } \\
\text { metal top. }\end{array}$ & & \\
\hline $\begin{array}{l}\text { Maestripieri and Alleva } \\
\text { (1990) }\end{array}$ & CD-1 (Charles River Italia) & $\begin{array}{l}33 \times 13 \times 14 \text { opaque plexiglas } \\
\text { cages }\end{array}$ & & \\
\hline $\begin{array}{l}\text { Mandillo and D'Amato } \\
\text { (1997) }\end{array}$ & $\begin{array}{l}\text { NMRI mice (Swiss-type, Plaisant, } \\
\text { Italy) }\end{array}$ & $\begin{array}{l}\text { Homecage: } 33 \times 13 \times 13 \mathrm{~cm} \\
\text { opaque plexiglas cages } \\
\text { (unclear, but mentioned in } \\
\text { description of other cage...) }\end{array}$ & & $\begin{array}{l}\text { Experimental apparatus: plexiglas cage }(40 \times 23 \times 15 \mathrm{~cm}) \text {, three } \\
\text { equal compartments }(13 \times 23 \times 15) \text { divided by transparent } \\
\text { plexiglas partitions, wood chips on floor. }\end{array}$ \\
\hline
\end{tabular}


Table 1. Housing conditions and strains used in the reviewed studies

Author, year $\quad$ Strain $\quad$ Barren cage $\quad$ Cage with nest ma

Complex cages structure / Furnished

Enclosure: Mouse-proof open-air barn. Floor concrete (48 m2), side walls sheet metal and hardware cloth with grids, dividing sections for spatial complexity of hardware cloth and

Local wild-caught mice crossed with four inbred strains: BALB/C, C57BL/6J, B10.BR, and DBA/1.

Laboratory:

Clear

polycarbonate

$(48 \times 27 \times 13 \mathrm{~cm})$

3-m spiral of hardware cloth $0.4 \mathrm{~m}$ high in the centre. Five widely spaced nest boxes in clear plastic added for thermal buffering. Total of 40 nestboxes and eight food and water stations. Hardware cloth platform $(1.5 \times 0.4 \mathrm{~m})$ suspended from the ceiling and accessed either end by $0.4 \mathrm{~m}$ wide strip of hardware cloth. The platform had a nest.

F2-F6 offspring of wild house mice

(Mus domesticus), offspring of wild mice crossed with Swiss Webster mice (CAMM Labs, NJ) and offspring of back-crosses of these hybrids.

$\mathrm{F}_{1}-\mathrm{F}_{4}$ offspring of wild house mice McCarthy and vom Saal (Mus musculus) trapped in Booune (1985) County, MO Stimulus pups $\mathrm{CF}-1$

$\mathrm{F}_{1}-\mathrm{F}_{4}$ offspring of wild house mice (Mus musculus) trapped in Booune McCarthy and vom Saal (1986) County, MO

CF-1 albino house mice, Charles River Farms, MA.

$\mathrm{F}_{1}-\mathrm{F}_{4}$ offspring of wild house mice (Mus musculus) trapped in Booune

McCarthy et al. (1986)
Polyethylene cage with pine

shavings.

Polypropylene cages

$(18 \times 29 \times 13 \mathrm{~cm})$ with pine

shavings.

\section{Polyethylene cages}

$(18 \times 29 \times 13 \mathrm{~cm})$ with pine

shavings.

\section{Polypropylene cages}

$(18 \times 29 \times 13 \mathrm{~cm})$ with aspen

bedding.

Test pups: CF-1 albino pups. 
Table 1. Housing conditions and strains used in the reviewed studies

\begin{tabular}{|c|c|c|c|}
\hline Author, year & Strain & Barren cage & Complex cages structure / Furnished \\
\hline Meek et al. (2001) & $\begin{array}{l}\text { Swiss-Webster mice from } \\
\text { breeding colony at University of } \\
\text { Minnesota, Morris. }\end{array}$ & $\begin{array}{l}\text { Clear, polycarbonate cages } \\
(27 \times 17 \times 13 \mathrm{~cm}) \text {. } \\
20 \text { days postmating females } \\
\text { housed singly in glass } \\
\text { aquaria }(40 \times 26,5 \times 20 \mathrm{~cm}) \\
\text { with } 5 \mathrm{~cm} \text { of aspen bedding. }\end{array}$ & \\
\hline
\end{tabular}

Members of a laboratory colony of

wild house mice descended from

Mendl and Paul (1990) mice caught in The Netherlands,

1971.

Housing conditions not mentioned

At arrival to laboratory in

groups of 10 in $40 \times 23 \times 15 \mathrm{~cm}$

cages.

Moles et al. (2004) NMRI mice

After weaning: males

housed in $33 \times 13 \times 13 \mathrm{~cm}$

cages. Housing conditions

at mating not mentioned.

Noirot (1974) Outbred albino population.

$\mathrm{B}_{6} \mathrm{D}_{2} \mathrm{~F}_{1}$ mice provided by Iffa-

Credo (France).

Pardon et al. (2000)

CD-1 mice, bred from stock

obtained from Charles River
Standard observation cage of transparent plastic $(37,5 \times 25,5 \times 16 \mathrm{~cm})$, wire-mesh container filled with pieces of

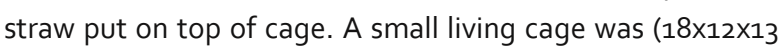
$\mathrm{cm}$ ) placed inside the large one and contained stimulus animals or remained empty. Breeding Laboratories.

Paul et al. (1980)

\begin{tabular}{lll}
\hline Peripato et al. (2002) LG/J and SM/J inbred lines Housing conditions not mentioned \\
\hline
\end{tabular}

Cage $(38 \times 22 \times 15 \mathrm{~cm})$ containing

sawdust (1L) and cotton wool (1g).

Opaque cages $(43 \times 23 \times 14 \mathrm{~cm})$ with

wire tops. Shredded newspaper

and paper towels as nesting 
Table 1. Housing conditions and strains used in the reviewed studies $\begin{array}{ll}\text { originally trapped in Canada. } & \\ \text { Strains: BALB/ALB and C57BL/ALB Housing conditions not mentioned }\end{array}$

Poley (1974)

$30 \times 23 \times 30 \mathrm{~cm}$. Rear and side walls

20 gauge galvanized mild steel

Priestnall (1972) $\quad \mathrm{C}_{3} \mathrm{H}$

sheet, front Plexiglas. Floor covered with sawdust and wood shavings, 3-4 g cotton for nest material.

Plastic laboratory cages $(33 \times 15 \times 13$

$\mathrm{cm})$, cage floors covered with sawdust, cotton-wool as nesting material (2-3 g)
Duplex (two pens)
polycarbonate cages,
$31 \times 31 \times 14 \mathrm{~cm}$, each pen
covered by wire-rod metal
top. Ventilated cages
covered by a snap-on filter
top. Autoclaved white pine
shavings used as bedding. 
Table 1. Housing conditions and strains used in the reviewed studies

\begin{tabular}{lll}
\hline Author, year & Strain & Barren cage with nest ma
\end{tabular}

Complex cages structure / Furnished

Test cages experiment $\mathrm{C}$ :

Cages contained bedding

Sayler and Salmon (1971)

$B A L B / C$ raised in the laboratory for (Sanicel).

several generations.

Size of cage not mentioned
Cage $(20,5 \times 36 \times 15,5 \mathrm{~cm})$ separated into two equal compartments by solid barrier. Nesting material (cotton) present in one of the test conditions.

Cage divided by wire mesh into three equal compartments (each $20,3 \times 17,8 \times 14,0 \mathrm{~cm}$ )

Experiment 1 and 2: Outbred stock

$\mathrm{HS} / \mathrm{lbg}$

Schneider and Lynch (1984)

Experiment 3: inbred strains

$\mathrm{BALB} / \mathrm{clbg}, \mathrm{C}_{3} \mathrm{H} / 2 \mathrm{lbh}, \mathrm{C}_{57} \mathrm{BL} / 6 \mathrm{~J}$,

$\mathrm{DBA} / \mathrm{BBG}$

Polypropylene cages

containing $500 \mathrm{ml}$ wood-

chip bedding, changed

twice a week.

Replicate 1: BALB/clbg, $\mathrm{C}_{57} \mathrm{BL} / 6 \mathrm{~J}$, $\mathrm{C}_{3} \mathrm{H} / 2 \mathrm{lbh}, \mathrm{DBA} / 1 \mathrm{BG}$

Schneider et al. (1982)
Polypropylene

containing $500 \mathrm{cc}$ wood chip

bedding, changed twice a

week.

On day 1 of testing: preweighed

amount of cotton batting

(Mountain Mist). Additional

preweighed cotton added if

necessary. 
Table 1. Housing conditions and strains used in the reviewed studies

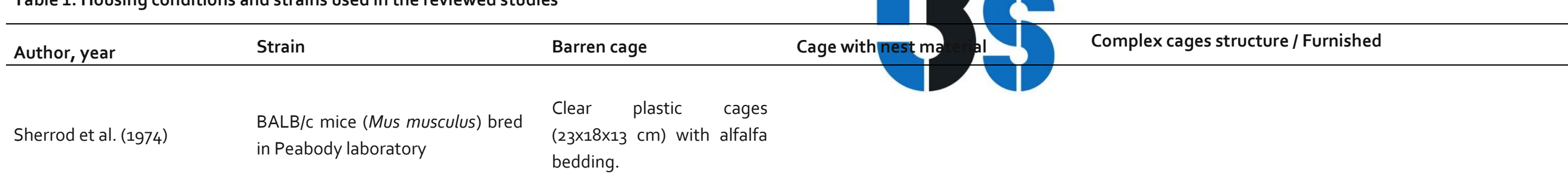

\section{Soroker and Terkel (1988) F1-F9 offspring of house mice}

trapped in the field (Israel).
Plastic cages $(28.5 \times 19 \times 13.5 \mathrm{~cm})$ divided in half by wire mesh partition, with wood shavings, inverted clay pot for shelter.

Rack systems: ventilated cabinet (Scantainer, Scanbur, Denmark); normal open rack; individually ventilated cage (VR-IVC, Charles River, Germany).

Enriched: Makrolon II, wood shavings for bedding, nest box, wood bar for climbing, nesting material (nestlets, cotton fibre, EBECO, Germany).

$\begin{array}{llll}\mathrm{DBA} / 2 \text { mice (Charles River, } & \begin{array}{l}\text { Makrolon } \\ (32.5 \times 16.5 \times 14 \mathrm{~cm}), \text { wood } \\ \text { Germany) }\end{array} \\ & \text { shavings for bedding }\end{array}$

Outbred stock of mice,

Vom Saal et al. (1995)

descendants of Mus musculus

trapped in Canada.
$43 \times 23 \times 13 \mathrm{~cm}$ polypropylene cages, aspen bedding. $10 \times 7.5 \times 7$ $\mathrm{cm}$ nestbox (could only be entered via tunnel, $7 \mathrm{~cm}$ long, $5 \mathrm{~cm}$ diameter), nesting material (Nestlet, Amcare, Manhasset, NY).

Woodwool given to pregnant mice, nests transferred at cleaning

until young begin to leave nest.
Cambridge/Wallace cage
Wallace (1981) Wild Mus musculus 
Table 1. Housing conditions and strains used in the reviewed studies

No wheel: $43.5 \times 23 \times 15.5 \mathrm{~cm}$

Wright and Brown (2000)
CD-1 Swiss Webster albino mice (Mus musculus) from Charles River Canada.
Wheel-noncontingent and Wheel-contingent: Specially constructed cages $(48.5 \times 21.5 \times 30.5 \mathrm{~cm})$, three sides of stainless steel, one side Plexiglas, removable stainless steel tray bottom, wire mesh lid. Running wheel $(8 \mathrm{~cm}$ wide, $17 \mathrm{~cm}$ diameter). 